OPEN ACCESS

Edited by:

Juliana Leme,

University of São Paulo, Brazil

Reviewed by:

Thomas Rich Fairchild,

University of São Paulo, Brazil

Guang-Hui Xu,

Institute of Vertebrate Paleontology

and Paleoanthropology, Chinese

Academy of Sciences, China

*Correspondence:

J. William Schopf

schopf@epss.ucla.edu

Specialty section:

This article was submitted to Paleontology,

a section of the journa

Frontiers in Ecology and Evolution

Received: 08 May 2021

Accepted: 09 August 2021

Published: 27 August 2021

Citation:

Schopf JW (2021) Precambrian Paleobiology: Precedents, Progress,

and Prospects.

Front. Ecol. Evol. 9:707072.

doi: 10.3389/fevo.2021.707072

\section{Precambrian Paleobiology: Precedents, Progress, and Prospects}

\author{
J. William Schopf* \\ Department of Earth, Planetary, and Space Sciences, University of California, Los Angeles, Los Angeles, CA, United States
}

In 1859, C. R. Darwin highlighted the "inexplicable" absence of evidence of life prior to the beginning of the Cambrian. Given this lack of evidence and the natural rather than theological unfolding of life's development Darwin espoused, over the following 50 years his newly minted theory was disputed. At the turn of the 19th century, beginning with the discoveries of C. D. Walcott, glimmerings of the previously "unknown and unknowable" early fossil record came to light - but Walcott's Precambrian finds were also discounted. It was not until the breakthrough advances of the 1950's and the identification of modern stromatolites (1956), Precambrian phytoplankton in shales (1950's), stromatolitic microbes in cherts (1953), and terminal-Precambrian soft-bodied animal fossils (1950's) that the field was placed on firm footing. Over the following halfcentury, the development and application of new analytical techniques coupled with the groundbreaking contributions of the Precambrian Paleobiology Research Group spurred the field to its international and distinctly interdisciplinary status. Significant progress has been made worldwide. Among these advances, the known fossil record has been extended sevenfold (from $\sim 0.5$ to $\sim 3.5 \mathrm{Ga}$ ); the fossil record has been shown consistent with rRNA phylogenies (adding credence to both); and the timing and evolutionary significance of an increase of environmental oxygen ( $2.3 \mathrm{Ga}$ ), of eukaryotic organisms ( 2.0 Ga), and of evolution-speeding and biota-diversifying eukaryotic sexual reproduction $(1.2 \mathrm{Ga})$ have been identified. Nevertheless, much remains to be learned. Such major unsolved problems include the absence of definitive evidence of the widely assumed life-generating "primordial soup"; the timing of the origin of oxygenic photosynthesis; the veracity of postulated changes in global photic-zone temperature from 3.5 Ga to the present; the bases of the advent of eukaryotic sexualityrequiring gametogenesis and syngamy; and the timing of origin and affinities of the small soft-bodied precursors of the Ediacaran Fauna.

Keywords: C. R. Darwin, great oxidation event (GOE), oldest fossils, Precambrian Paleobiology Research Group (PPRG), C. D. Walcott

\section{EXPLANATORY COMMENT}

Unlike the Editors and publishers of this volume, please note that I prefer to refer to this field of science as "Precambrian Paleobiology" - rather than "Precambrian Paleontology" - chiefly because the suffix "-biology" emphasizes its necessarily interdisciplinary character, a hallmark of the field that contrasts rather markedly from the long-established practices of Phanerozoic 
paleontology. In addition, being the last surviving member of the so-called "vanguard" of workers in such Precambrian studies (Cloud, 1983) and having spent some 60 years investigating numerous aspects of the early history of life, please also note that this review article is written from my personal perspective.

\section{BEGINNINGS OF THE SCIENCE}

\section{9, Darwin's Dilemma}

In 1859, Charles Robert Darwin stated the problem: "If the theory [of evolution] be true, it is indisputable that before the lowest Cambrian stratum was deposited... the world swarmed with living creatures. [Yet] why we do not find rich fossiliferous deposits belonging to these assumed earliest periods. . I can give no satisfactory answer. The case at present must remain inexplicable; and may be truly urged as a valid argument against the views here entertained" (Darwin, 1859, Chpt X).

Darwin's evidence for his theory came not only from the multitude of specimens he collected as the naturalist on the 1831-1836 world-encircling voyage of the H.M.S. Beagle but even more-so from the then already reasonably well-outlined Phanerozoic fossil record. In Darwin's time, however, the history of life prior the emergence of the oldest Cambrianage invertebrate animal fossils was completely unknown, a deficiency that plagued Darwin and his theory. And though Darwin tried mightily to explain the problem away (perhaps primitive life was too small, too fragile to be preserved, or perhaps all truly ancient fossil-hosting rocks had eroded away), his notions about pre-trilobite pre-Cambrian life and the early rock record were mistaken. Nevertheless, for the following full century, from the 1860's to the 1960's, the Precambrian history of life was regarded as "unknown and unknowable," claimed by some to be "the greatest unsolved problem in all of natural science."

\section{0-1900, Distrust of Darwin's Evolution}

As with all newly minted paradigms, Darwin's evolution addressed a previously unquestioned explanation of a major aspect of human understanding, namely the history and development of life on Earth. Throughout all of Europe for the previous nearly two millennia - dating from the Roman Empire that stretched across North Africa and from Italy to the British Isles - the prevailing view was that God, as documented in the Holy Christian Bible, had created all of life. Darwin's theory of a naturally occurring rather than a Biblically ordained unfolding of life's development flew in the face of accepted wisdom.

Darwin and his "Bible-disproving" ideas were soon lampooned in the British press, a pervasive criticism that spread the colonies. A prime example and strident critic was John William Dawson, appointed in 1855 to the influential position of Principal of McGill University, Canada, who was knighted by Queen Victoria in 1884. Of Scottish descent and a Calvinist staunch Creationist, in 1865 Dawson formally described Eozoön canadense, the "Dawn Animal of Canada" (Figure 1), a large multi-layered structure found in pre-trilobite, pre-Cambrian limestones near the Ottawa River west of Montreal, rocks

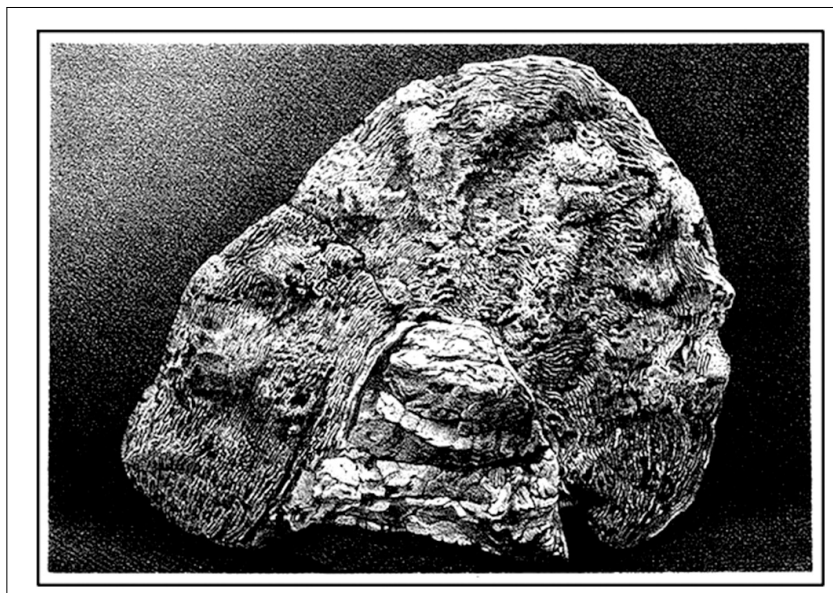

FIGURE 1 | J. W. Dawson's "Dawn Animal of Canada," Eozoön canadense, a specimen of non-biogenic seperpentinized limestone $\sim 20 \mathrm{~cm}$ in largest dimension collected in early Neoproterozoic strata southwest of Quebec Canada, as depicted in The Dawn of Life, 1875, Plate III, p. 35.

now known to be $\sim 1,100 \mathrm{Ma}$ in age. Even though Eozoön was quite obviously far older than any fossils then known, Dawson regarded it to be assuredly biogenic, interpreting it to be the remains of a giant foraminiferal protozoan and - to him of utmost importance - direct evidence that disproved Darwin's theory. As he wrote in his 1875 volume The Dawn of Life, "There is no link whatever to connect Eozoön with younger fossils. . all stand before us as distinct creations. Eozoön thus bears damaging negative testimony against evolution [a theory that] is incapable of proof and contrary to fact. Evolutionists are mere dreamers, having no scientific basis for their dogmas" (Dawson, 1875, Chpt. VIII).

Eozoön was soon discounted. In 1866, a year after its announcement, Irish mineralogists William King and Thomas Rowney opined that the supposed fossil was "purely mineralic, non-biologic." In 1879, based on studies of specimens sent to him by Dawson, the German zoologist and world expert on the Foraminifera Karl Möbius agreed with the King-Rowley assessment, writing that Eozoön was "certainly not biologic." Finally, in 1894, two geologists at London's British Museum, J. W. Gregory and H. J. Johnston-Lavis, collected specimens of Eozoön in volcanic blocks at Mt. Vesuvius in southern Italy and found them to be composed of coarsely crystalline calcite and serpentine, thus identifying Dawson's "Dawn Animal" as a "serpentinized limestone, entirely inorganic." In short - and though until his death in 1899, Dawson continued to maintain that he had "disproved evolution" - Eozoön has the unwelcome distinction of being the first Precambrian pseudofossil discovered and formally described.

\section{0-1950, Stage-Setting Events}

In the late 1800's, the American paleontologist Charles Doolittle Walcott entered the scene, a history masterfully recounted in the writings of Ellis Yochelson of the United States National Museum of Natural History (Yochelson, 1998). As a youth, Walcott attended Utica High School in upstate New York from which he 


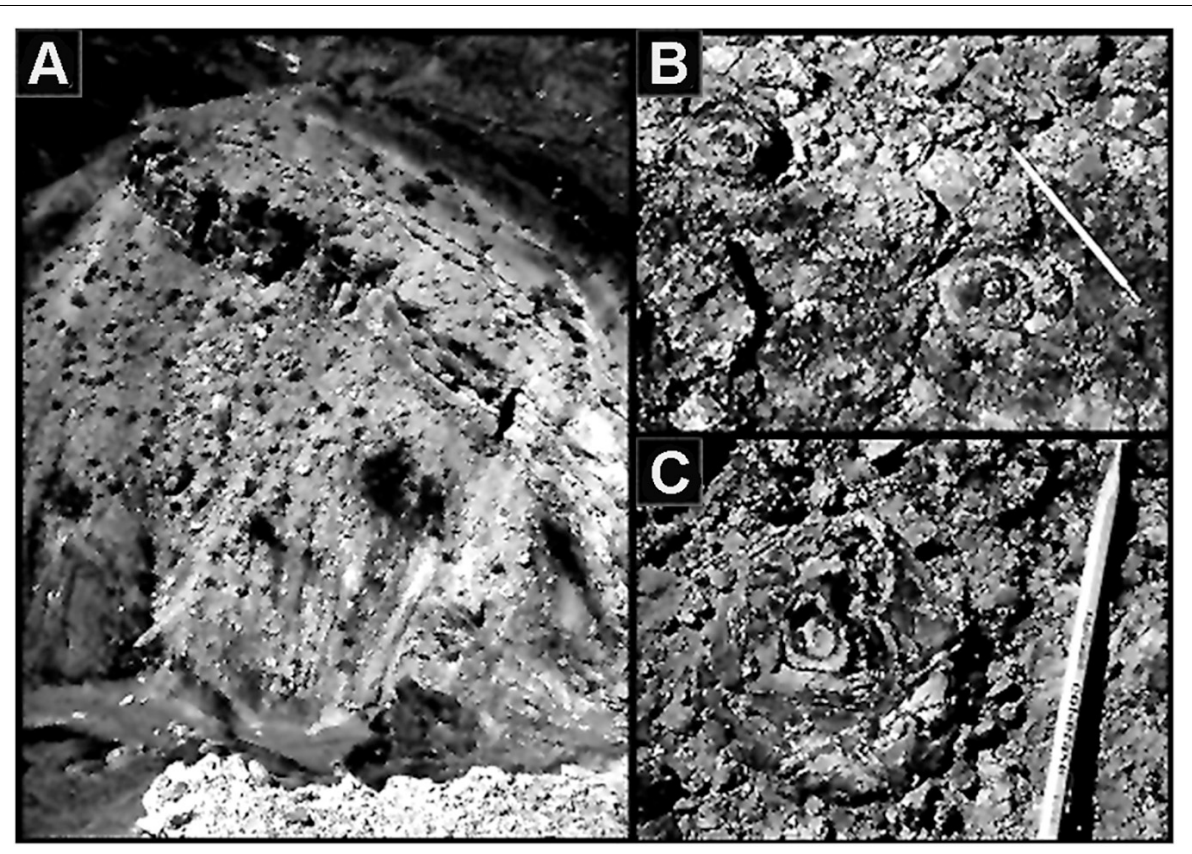

FIGURE 2 | (A) "Stromatolite Ridge" in the Neoproterozoic 750 Ma Chuar Group Galeros Formation of the Grand Canyon of Arizona United States where C. D. Walcott discovered the Cryptozoön -like stromatolites shown in $\mathbf{( B , C ) , ~ t h e ~ f i r s t ~ s t r o m a t o l i t e s ~ t o ~ b e ~ r e p o r t e d ~ f r o m ~ t h e ~ P r e c a m b r i a n ~ r o c k ~ r e c o r d . ~}$

departed at the age of 18 - two years before he was to graduate and after only 10 years of formal schooling. He then became a farmhand, toiling the fields and, in that process, augmenting the impressive collection of Cambrian trilobites he had begun to amass as a youth. Soon after being hired in 1876 by N.Y. State Geologist James Hall Jr., in 1879 Walcott was recruited to join the newly formed United States Geological Survey (USGS).

At about that time the recently appointed USGS Director, John Wesley Powell, set in place a series of expeditions down the Colorado River through the Grand Canyon of Arizona, each a harrowing passage down the rushing waters on large rowboats and unstable log rafts. Walcott eagerly signed-up. On one of the early ventures, in 1883, he discovered the first stromatolites known from the Precambrian rock record (Figure 2), layered microbe-produced mound-shaped structures much like the Cambrian "algal reefs" at Saratoga Springs NY that Hall had previously named Cryptozoön (meaning "hidden life") and that Walcott had examined in 1878. This was an important "first," stromatolites being now known to be both widespread and abundant in shallow-water marine strata throughout the Precambrian, the oldest dating from the beginning of the Paleoarchean.

On a later Grand Canyon trip, Walcott uncovered another major find, compressed specimens of the Precambrian spheroidal planktonic alga Chuaria (Figure 3) which he formally described and named in 1899 (Walcott, 1899). Although specimens much like Chuaria had previously been recorded from the $\sim 800 \mathrm{Ma}$ Neoproterozoic Visingsö Group of Sweden, they were unnamed and had not been illustrated (reviewed by Talyzina, 2000). Thus, Walcott deserves the credit for having formally described the first cellularly preserved Precambrian microfossils known to science.

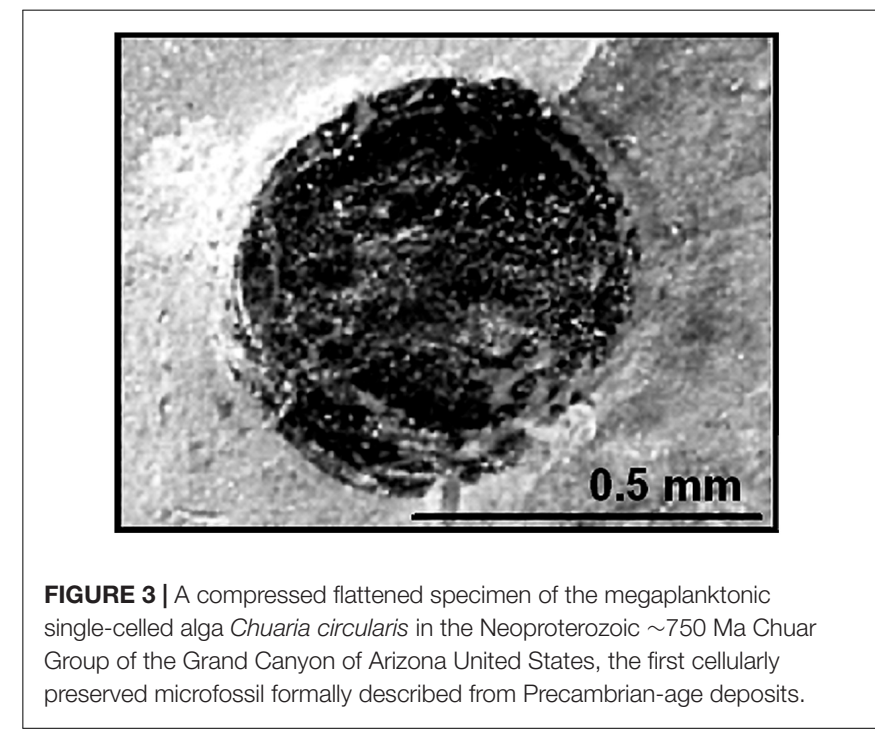

In the following years, Walcott headed north along the spine of the Rocky Mountains and from 1902 to 1907 discovered numerous close-packed Precambrian stromatolites in the Lewis Range of northwestern Montana, important confirmation of his earlier discovery of their occurrence in the Chuar Group Grand Canyon strata. From there, he continued even farther north, up the Rocky Mountains into British Columbia where in 1909 he yet again had a huge success, discovery of the remarkably diverse and well-preserved animal fossils of the middle Cambrian (510 Ma) Burgess Shale, the all-important first prime evidence of the Cambrian Explosion of Life. 
Walcott's career was spectacular. After joining the USGS in 1879 , he rapidly rose through the ranks, in 1893 becoming Chief Paleontologist and then, in 1894 with the retirement of J. W. Powell, he was appointed the second Director of the United States Geological Survey. For Walcott, that was just the beginning. In 1902, he and a team of colleagues met with the exceedingly wealthy "Robber Barron" philanthropist Andrew Carnegie and established the Carnegie Institution of Washington to promote scientific discovery that from its inception has remained a highly distinguished research center. Walcott later went on to become Secretary (CEO) of Washington's Smithsonian Institution, President of the National Academy of Sciences, and President of the American Association for the Advancement of Science. Additionally, as a close advisor to United States President Theodore Roosevelt, he was instrumental to the establishment of the United States National Park system.

Despite these accomplishments, not all of Walcott's finds were warmly received, most notably his claims of Precambrian life (stromatolites and cellular fossils). Walcott had ascended to scientific stardom so it would take another luminary to take him down. Albert Charles Seward, Vice-Chancellor (CEO) of Cambridge University United Kingdom and the world's leading paleobotanist, filled the bill. Delivering his verdict from his position of unquestioned authority - Walcott's Precambrian finds being evidence of ancient algae and microbes and, thus, under the purview of paleobotany - Seward lowered the boom in his 1931 textbook, his discussion being brief but to the point. According to Seward, "[Walcott's interpretation of] Cryptozoön [the Precambrian stromatolites] is, I venture to think, not justified by the facts. It is clearly impossible to maintain that such bodies are attributable to algal activity. . . we can hardly expect to find in Pre-Cambrian rocks any actual proof of the existence of bacteria." Seward's assessment of Walcott's discoveries then concluded with a bit of artful doggerel about Walcott's Precambrian finds: "Creatures borrowed and again conveyed, from book to book the shadows of a shade" (Seward, 1931, pp. 86, 87). Walcott could not offer a rejoinder - he had died 4 years before Seward's views were published.

Walcott's problem was that the Precambrian fossils he reported were not only previously unknown but were far too old to fit the widely accepted dogma. Nevertheless, numerous paleontologists were intrigued by Walcott's reports (perhaps the best known being Harvard's Percy E. Raymond) and investigated his finds, primarily in the Rocky Mountains of Montana. Walcott's reports of Precambrian stromatolites were easily confirmed, but the biological origin of these enigmatic structures remained in dispute as it had been since the early 1800's (their lithified modern analogs remaining undiscovered until 1956). And Walcott's claim of Precambrian cellular fossils fell to the wayside, his well-intentioned followers repeatedly misinterpreting encrusting mud flakes and similar mineralic objects as bits and pieces of bona fide fossils, chiefly trilobite carapaces. From then on, not surprisingly, the scientific community regarded any claim of the discovery of evidence of Precambrian life with unbridled skepticism.

In retrospect, we can now see that C. D. Walcott had brought the study of Precambrian fossils to the brink of success, only to have his prescient findings dismantled by the errors of his fellow paleontologists and demolished by Seward's authoritative assertions.

\section{0-1965, Breakthrough Advances}

In the 1950's and 1960's the tide began to turn, four initially seemingly unrelated field-charting breakthroughs dating from this seminal period.

\section{Modern Stromatolites}

The possible biogenicity of stromatolites, a subject of controversy since the early 1800's, was finally laid to rest in 1956 by Australian geologist Philip Playford who discovered living examples at Hamelin Pool, Shark Bay Western Australia. The modern forms, laminated mound-shaped structures lithified by precipitated calcium carbonate in the intertidal regions of this hypersaline lagoon (Figure 4), were in numerous respects similar to Hall's Cambrian-age Cryptozoön "algal reefs.” Playford gave specimens from the site to Brian W. Logan, a graduate student at the University of Western Australia who by identifying their matbuilding cyanobacterial components established their biogenicity (Logan, 1961). Though this was a major step forward for studies of Precambrian life - at present, stromatolites being known from shallow marine environments throughout the Precambrian rock record - it would not have been a surprise to the microbiological community, the unlithified equivalents of stromatolites having been referred to by microbiologists since the early 1900's as "microbial mat communities."

\section{Microfossils in Shales}

A second breakthrough advance came from the studies of Boris Vasil'evich Timofeev and his assistant Tamara Nikolaevna Hermann of the USSR Institute of Precambrian Geochronology in Leningrad (now St. Petersburg, Russia). In the late-1950's they initiated studies of microfossils in Precambrian shales, using the acid-maceration technique well known to palynologists and other micropaleontologists. Of their many seminal studies,

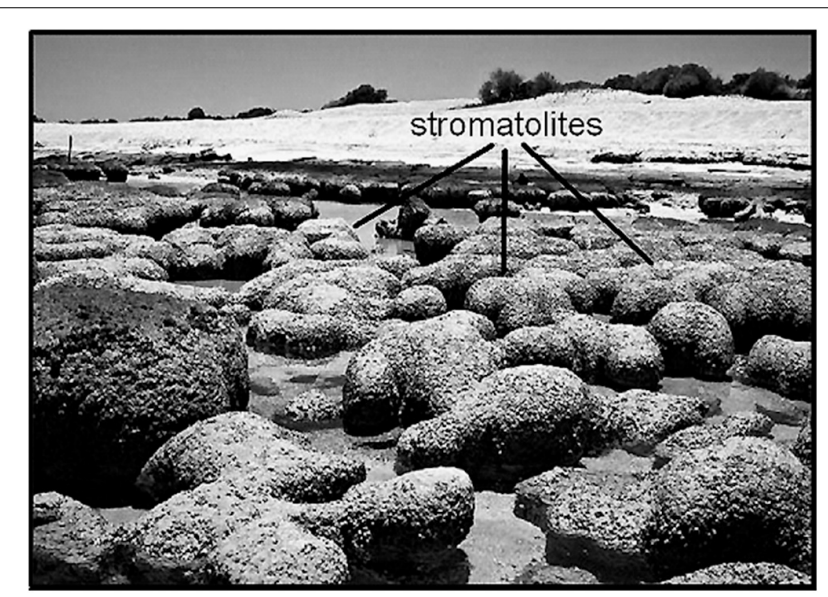

FIGURE 4 | Modern carbonate-lithified stromatolites discovered by P. Playford in the intertidal zone of Hamelin Pool, Shark Bay, Western Australia, shown here at low tide. 
perhaps the best known is their 1979 discovery of the $\sim 1,020 \mathrm{Ma}$ Lakhanda Microflora of southeastern Siberia, among the oldest highly diverse phytoplankton-dominated biotas yet discovered (Timofeev and Hermann, 1979). Due to international politics and the then on-going East-West Cold War, the TimofeevHermann findings were for many years little known and rarely credited among the non-Soviet scientific community. Nevertheless, their groundbreaking studies have proven to be a prime factor in stimulating paleobiologic investigations of Precambrian carbonaceous shales worldwide.

\section{Microfossils in Cherts}

Here the major credit for the science-changing discovery belongs to Stanley A. Tyler, an economic geologist at the University of Wisconsin who in 1953 discovered microscopic fossils in stromatolitic carbonaceous cherts of the $\sim 1,900 \mathrm{Ma}$ Gunflint Formation of Ontario Canada, an iron-rich unit he was studying because of its economic importance to the Lake Superior-encircling taconite industry. Unschooled in paleontology, Tyler sought the advice of paleontologist Robert Shrock of the Massachusetts Institute of Technology who introduced him to Harvard's paleobotanist, Elso S. Barghoorn. In 1954, they published a paper announcing their discovery of cellularly preserved Paleoproterozoic fossil microbes (Tyler and Barghoorn, 1954).

During the following several months, Tyler prepared a manuscript illustrating the fossils and reporting the geologic details of the find to which Barghoorn was to add formal taxonomic descriptions of the newly discovered microbes. Unfortunately, however, due to a series of unforeseen difficulties the manuscript remained unattended until a decade later, finally published in 1965 (Barghoorn and Tyler, 1965) and less than a year after Tyler's unexpected death. Although the paper illustrated numerous obviously cellularly preserved ancient microbes (Figure 5), given the long-established dogma that Precambrian life was "unknown and unknowable" it is perhaps not surprising that this paper met with widespread skepticism, the critics opining publicly and privately that "the 'fossils' are far too old. . simply not believable... there must be some mistake!" Some 6 months later a second report of chertpreserved Precambrian fossils appeared (Barghoorn and Schopf, 1965 ), this time from the $\sim 850$ Ma Bitter Springs Formation of central Australia. In the development of the science, this second 1965 paper proved to be the "deal-sealer" - different rocks, different continent, different age, and chock-full of abundant, varied, remarkably well preserved microscopic fossils, many easily relatable to microbes living today (Figure 6). Taken together, these two seminal papers laid a firm foundation for the now thriving field of Precambrian paleobiology, especially after they were updated by the addition of new telling data, for the Gunflint assemblage by Awramik and Barghoorn (1977) and for the Bitter Springs Microbiota by Schopf (1968) and Schopf and Blacic (1971).

\section{Precambrian Animal Fossils}

The fourth in this series of breakthrough discoveries dates to 1946 and the work of Reginald Claude Sprigg, an Australian geologist who discovered imprints of fossil jellyfish in strata of the Pound Quartzite in the Ediacara Hills north of Adelaide, South Australia. Sprigg named the fossils Mawsonites in honor of the Australian geologist and Antarctic explorer Douglas Mawson, but being uncertain of the fossils' age, Sprigg assumed they were most likely Cambrian.

Beginning in 1950, with the arrival at the University of Adelaide of paleontologist Martin Fritz Glaessner, the situation markedly changed. Indeed, by the end the 1950's, aided by his assistant Mary Julia Wade, Glassner uncovered firm evidence showing that not only were the fossils pre-trilobite and preCambrian (if barely so) but that the fauna was richly diverse, including many soft-bodied animals previously unknown to science (Figure 7). Like the reticence toward Walcott's earlier breakthrough finding of Precambrian stromatolites and fossil phytoplankton, Glaessner's discoveries were a poke in the eye to traditionalists who were convinced that it was impossible for preCambrian animals to exist .. . "after all," the naysayers exclaimed, "that is the way the beginning of the Cambrian Period of geological history is defined!"

A prime leader of this traditionalist school was Preston Ercelle Cloud, Jr. Over time, the Glaessnerian and Cloudian views of the definition of the base of the Phanerozoic Eon came to loggerheads. Glaessner argued that a new geological period should be established to include pre-trilobite soft-bodied animals. Cloud argued the opposite, that the base of the Cambrian should simply be extended downward, that no new geological period was needed. Clearly, Cloud's idea would not work - each new sequentially older finding would require that the Phanerozoic-Precambrian boundary be moved to a lower stratigraphic level making it impossible to be certain when the Phanerozoic truly began. But Glaessner's idea was at odds with long-established practice. The controversy was ultimately resolved by the International Commission on Stratigraphy and ratified in 2004 by the International Union of Geological Sciences (IUGS), establishing the first new geological period declared in 120 years - the 635-541 Ma Ediacaran Period, assigned to the uppermost Precambrian, not the overlying Phanerozoic.

\section{NEW TECHNIQUES}

Breakthrough discoveries are fundamentally defined by that which has not been known before, a lack of knowledge that in turn is not uncommonly a function of the techniques and instrumentation available to carry out the evidence-providing investigations. Thus, realization that the Precambrian fossil record was dominated by carbonaceous microscopic organisms rather than the skeletonized remains of Phanerozoic megascopic animals familiar to paleontologists presented a major challenge to the community, one difficult to meet by use solely of longestablished research techniques. Not surprisingly, therefore in part concurrent with but largely subsequent to the seminal discoveries noted above - a series of new techniques emerged, many now used routinely worldwide. Although the following synopsis focuses on the innovative techniques applied to 


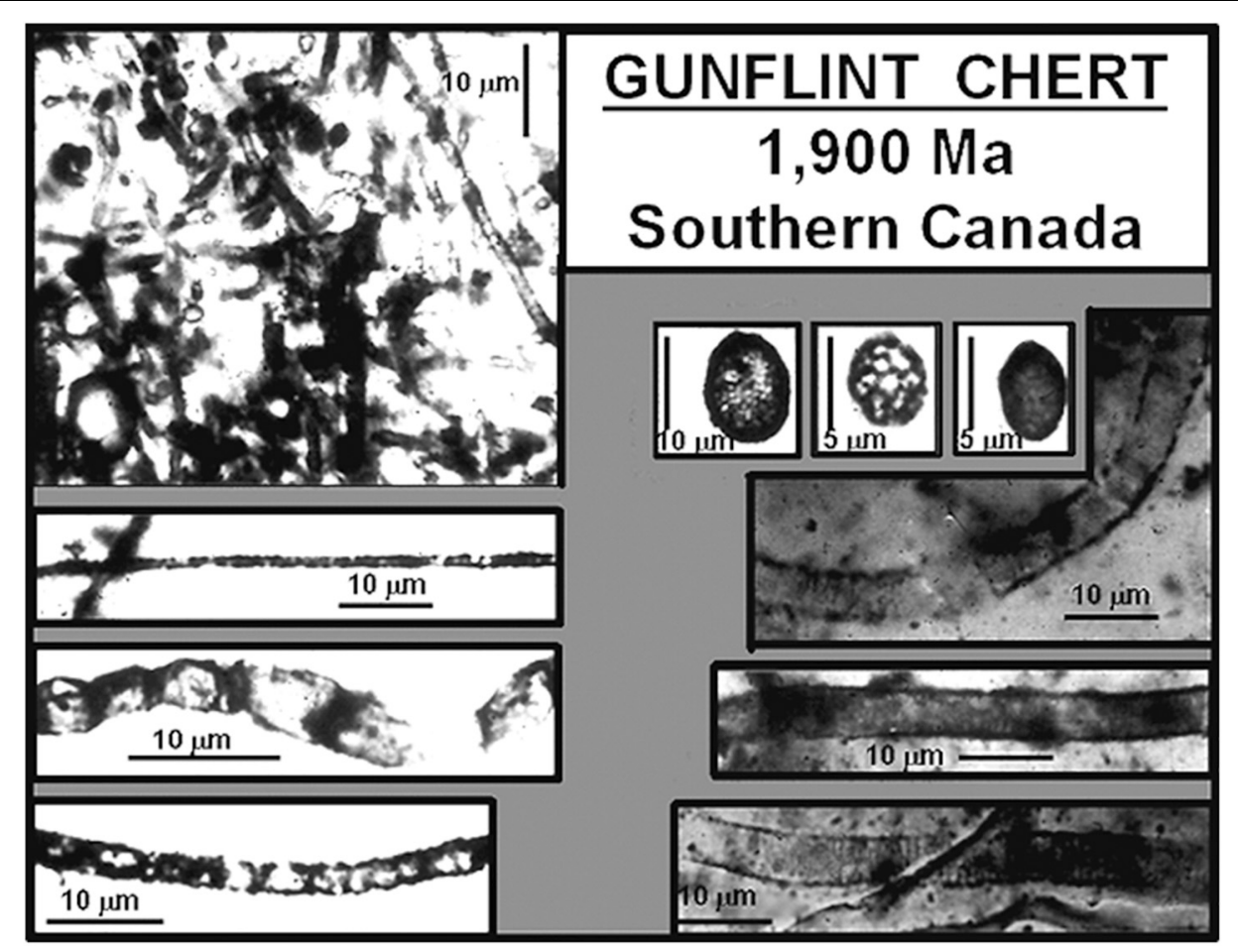

FIGURE $\mathbf{5}$ | Representative filamentous and ellipsoidal fossil microorganisms preserved by permineralization in large, meter-diameter mound-shaped carbonaceous stromatolites of the Paleoproterozoic $\sim 1,900$ Ma Gunflint chert of southern Ontario Canada.

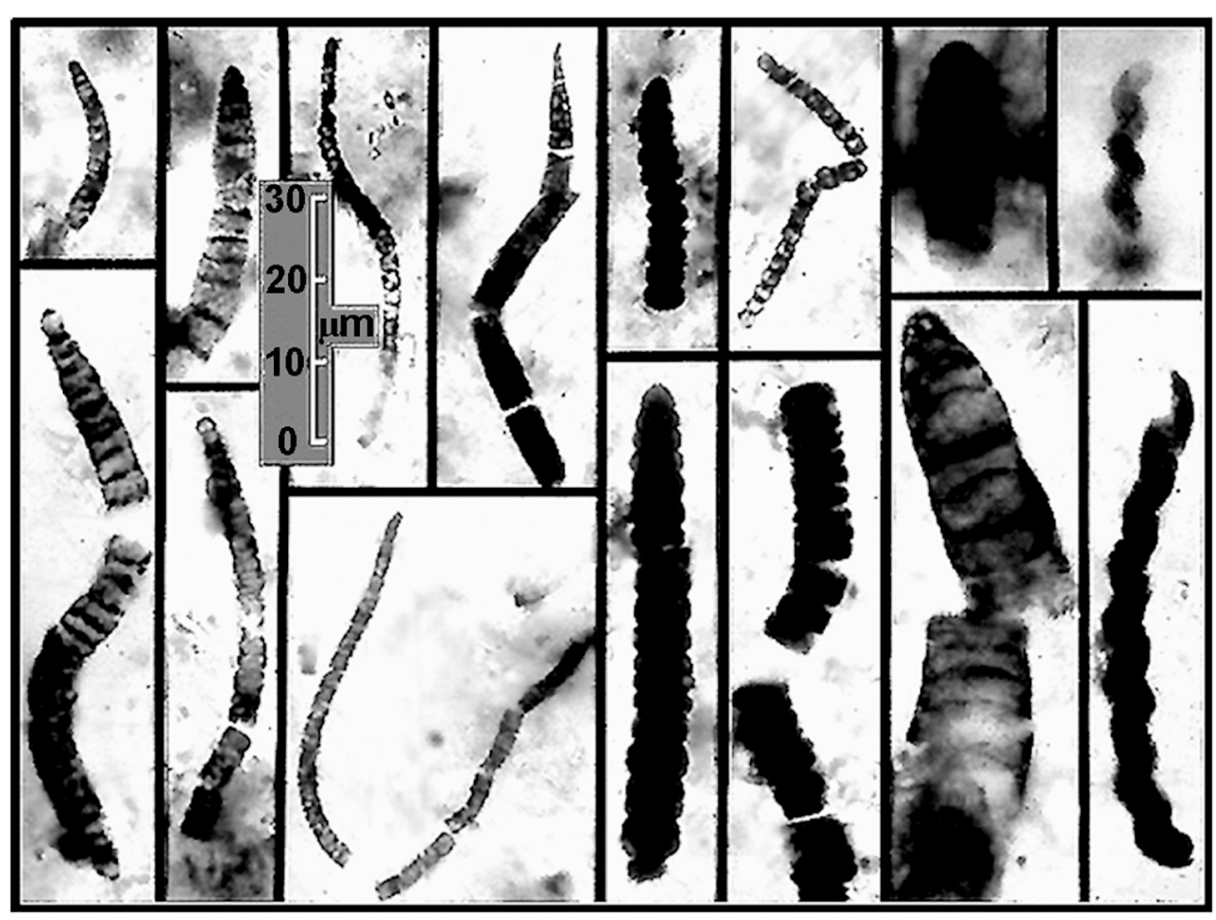

FIGURE 6 | Representative fossil Oscillatoriacean and Nostocacean cyanobacteria preserved by permineralization in flat-lying carbonaceous black chert stromatolites of the Neoproterozoic $\sim 850 \mathrm{Ma}$ Bitter Springs Formation of central Australia deposited in a quiescent, probably lagoonal setting. In both organismal and cellular morphology, the specimens shown are essentially indistinguishable from modern species of such cyanobacteria as Oscillatoria, Rivularia, Spirulina, and Nostoc. 

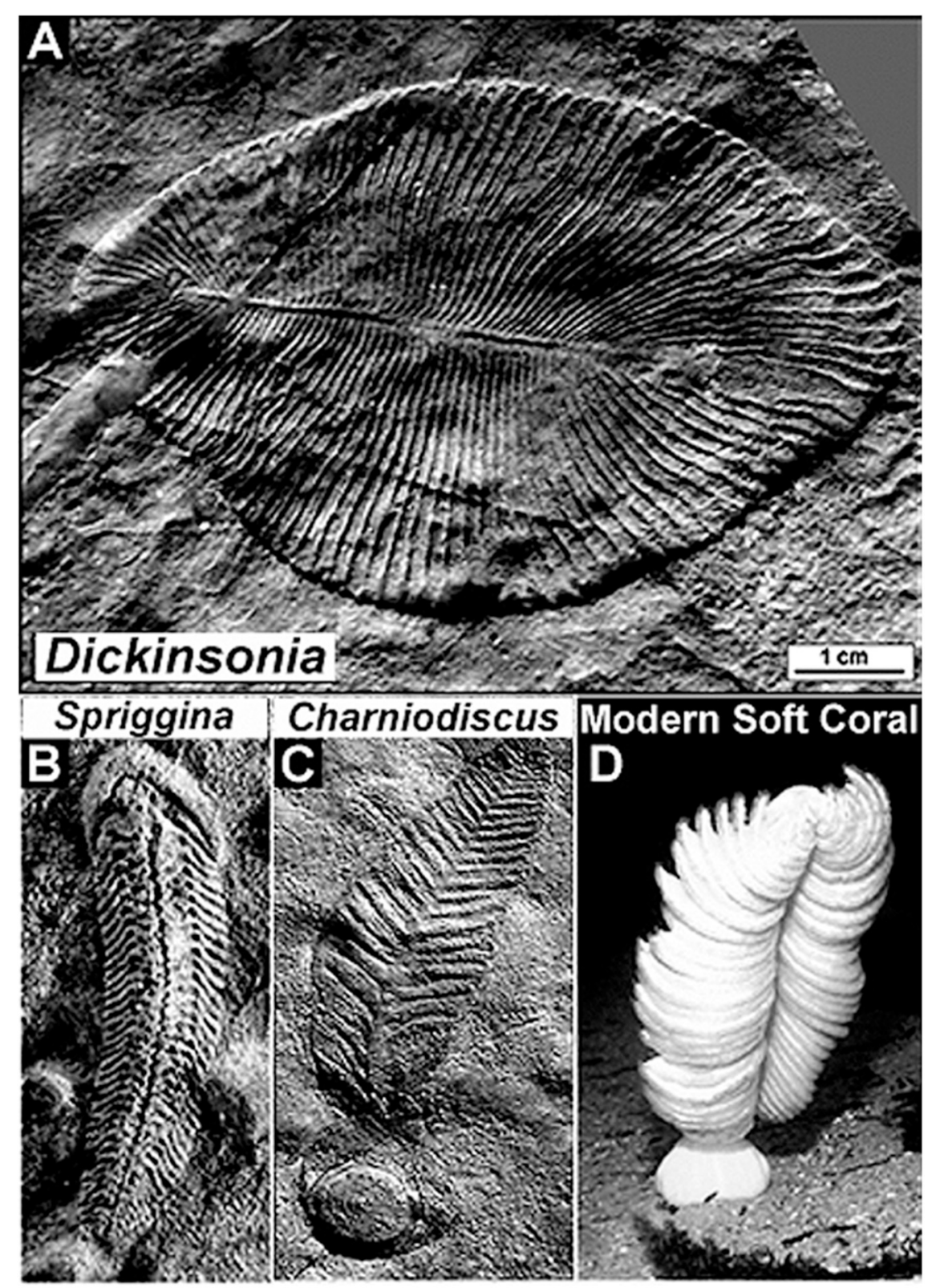

FIGURE 7 | Representative soft-bodied animal fossils of the latest Neoproterozoic Ediacaran Fauna of the Pound Quartzite of South Australia. (A) Dickinsonia, a disk-shaped worm-like animal. (B) Spriggina, a polychaete worm-like animal and the oldest known fossil to exhibit an identifiable head, thickened to protect its contained sensory apparatus. (C) Charniodiscus, a stationary animal that lived anchored to the sandy seabed held in place by a basal holdfast, an Ediacaran fossil similar to (D) a modern soft coral.

studies of microscopic Precambrian fossils, several have also been used quite effectively in investigations of early-evolved metazoans.

The breakthrough Timofeev-Hermann studies of shale microfloras and Tyler-Barghoorn-Schopf chert microbiotas discussed above highlight the differences in preservation between these two matrices. Fossils preserved in shale are compressed, flattened and commonly distorted, best studied freed from their matrix in acid macerations. In contrast, microfossils permineralized in chert are three-dimensional and cellularly intact, the permineralizing microcrystalline silica having infilled and replaced watery spaces within the cells and cell walls to produce unflattened "life-like" geochemically altered carbonaceous fossils that are studied most effectively in situ, embedded within petrographic thin sections. Of the two types of preservation, three-dimensional permineralization (whether in silica, calcite or gypsum) is clearly the paleontologically preferable, providing far more little altered morphological information by which to assess the biological affinities of the fossils studied. 


\section{Photomontage}

Despite the obvious advantages of permineralized fossils, their study presents problems, primarily and ironically because of their "life-like" three-dimensional form. The great majority of Precambrian fossils are microscopic, their detailed study requiring high-resolution $100 \times$ oil-immersion optical microscopy. Moreover, most are minute sinuous cellular filaments that bend in and out of a single thin optical plane whereas others comprise larger three-dimensional colonies that cannot be depicted in a single thin in-focus high magnification photomicrograph. To address these problems, in 1968 the technique of photomontage was introduced (Schopf, 1968), a matter of literally pasting together a series of photomicrographs taken at sequential optical depths to thereby reconstruct the three-dimensional form of a fossil studied (Figure 8). This simple technique, an innovation necessary for the publication of research findings and immediately adopted by workers worldwide, is now accomplished far easier by use of the Photoshop computer program.

\section{Electron Microscopy}

In the 1960's and 1970's, transmission electron microscopy (TEM) and scanning electron microscopy (SEM), both techniques having exceptionally high spatial resolution and both borrowed from the biological sciences, were first applied to Precambrian microbes. TEM was used to identify bacteriumlike fossils in the $\sim 1,900 \mathrm{Ma}$ Gunflint chert (Schopf et al., 1965 ) and, a few years later, to document the preservation of nuclei in permineralized unicellular phytoplankton of the $\sim 850 \mathrm{Ma}$ Bitter springs Formation (Schopf and Oehler, 1976). Similarly, SEM proved useful to analyze diverse

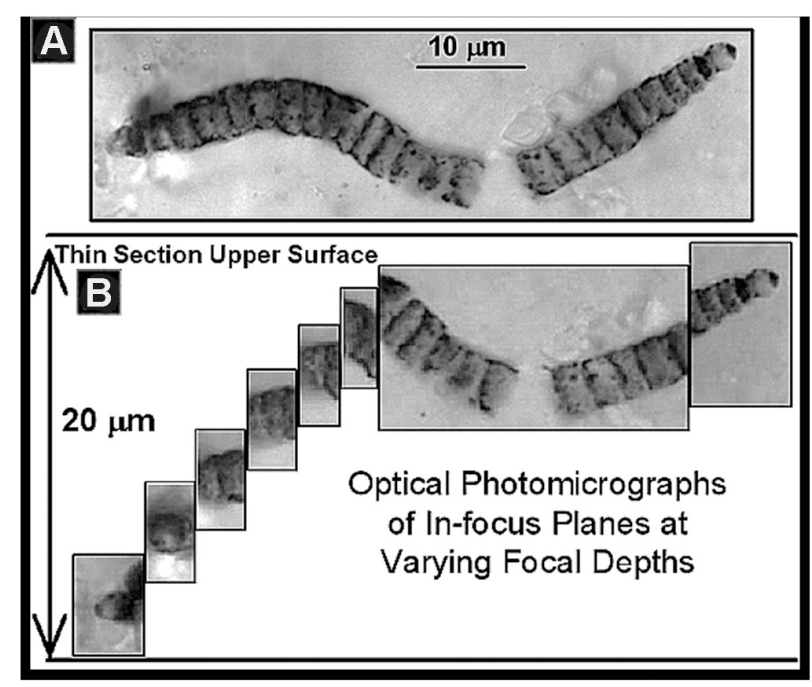

FIGURE 8 | (A) A photomontage of the fossil Oscillatoriacean cyanobacterium Cephalophytarion chert-permineralized in the Neoproterozoic $~ 850 \mathrm{Ma}$ Bitter Springs Formation of central Australia. (B) The series of photomicrographs of optically in-focus planes from which this montage was constructed showing that the fossil plunges into the thin section to a depth of $20 \mu \mathrm{m}$.
Precambrian microbes isolated from their encompassing matrices by acid maceration (Schopf, 1970; Schopf and Blacic, 1971). Such studies have continued to the present, most recently illustrated by the use of SEM to document filamentous fungi and associated siphonalean green algae in Ediacaran stromatolites of the southern Siberian Platform (Kolosov, 2016).

\section{Secondary Ion Mass Spectrometry}

The introduction of secondary ion mass spectrometry (SIMS) in the field of geochemistry, where it was primarily applied to analyzing the carbon isotopic composition of isolated Archean zircon grains, represented a promising opportunity to Precambrian paleobiology by which to document the metabolism-indicating carbon isotopic signatures of individual microscopic fossils. SIMS was first applied to Precambrian microfossils in 2000, an analysis of the carbon isotopic composition of microfossils permineralized in the $\sim 850 \mathrm{Ma}$ Bitter Springs Formation of central Australia selected for this initial study because it would permit the SIMS data to be compared with a body of previously obtained bulk carbon isotopic measurements of co-occurring detrital carbonaceous matter. The veracity of the SIMS data was thus confirmed (House et al., 2000) and, like the use of photomontage, this technique, where available, has been applied in numerous studies worldwide.

Nevertheless, and although the application of secondary ion mass spectrometry to analyses of ancient microscopic fossils was a major step forward in Precambrian paleobiological studies, its use has drawbacks. The required equipment is expensive and not widely available, and though SIMS establishes the metabolism-evidencing carbon isotopic composition of the fossils analyzed, its application is exceedingly time-consuming and limited to single fossils exposed at the upper surface of a petrographic thin section.

\section{Raman Spectroscopy}

What was needed was a faster more widely applicable technique, one that could not only establish the carbonaceous composition of the fossils analyzed but that could also document their morphology and molecular chemical signature at depth below the thin section surface. This need was soon met by the introduction to such studies of Raman spectroscopy. As first illustrated by analyses of microfossils of the $\sim 3,465 \mathrm{Ma}$ Apex chert of Western Australia (Kudryavtsev et al., 2001; Schopf et al., 2002), Raman spectra establish the molecularstructural carbonaceous composition of minute Precambrian permineralized fossil microbes whether surface-exposed or rockencased and plunging below the surface of a translucent thin section (Schopf and Kudryavtsev, 2005). Moreover, and at the same submicron spatial resolution, such spectra can be used to document the mineralogy of the fossil-hosting matrix, the three-dimensional cellular morphology and molecular chemistry of the fossils studied, and establish as well, by use of the Raman Index of Preservation (RIP), the fidelity of preservation of their macromolecular carbonaceous components (Schopf et al., 2005). 


\section{X-Ray Tomography}

In 2003, yet another new analytical technique was introduced, $\mathrm{X}$-ray microtomography (XTM). Unlike the previously discussed techniques, XTM was initially used for analyses of Neogene hominids (Chaimanee et al., 2003) and, soon thereafter, Phanerozoic fossil plants and amber-entombed insects (Feist et al., 2005; Tafforeau et al., 2006; Friis et al., 2007). Like TEM, SEM and SIMS, XTM is a high-resolution technique primarily useful for analyses of surface-exposed specimens and, thus, has been used principally to investigate the morphological characteristics of specimens separated from their rock matrices by acid maceration. Notably, however, and unlike these other techniques, XTM permits 3-D examination of such specimens from multiple vantage points and visualization of their internal structures. In studies of Precambrian fossils, XTM has been used for analyses of 600-800 $\mu \mathrm{m}$ diameter metazoan embryos and their contents phosphatized in the Wengan biota of the Ediacaran Doushantuo Formation of southwest China (Chen et al., 2006, 2009; Donoghue et al., 2006; Tafforeau et al., 2006), studies recently amplified and expanded by Yin et al. (2020). Given this success, increased application of XTM can easily be predicted.

\section{Confocal Laser Scanning Microscopy}

With these advances - photomontage, electron microscopy, SIMS, 2-D and 3-D Raman spectroscopy, and X-ray tomography - most of the obvious instrumental needs of the field had been addressed. But one glaring deficiency remained, namely, what additional information about the taxonomically crucial morphology of such minute objects could be gleaned by imagining them in situ, embedded in their rock matrix, at high resolution and not only from their top, as required by most of these techniques, but by visualizing them from their sides and bottoms as well? This final problem was answered in 2006 by the introduction to paleobiological studies of 3-D confocal laser scanning microscopy (CLSM), a high-resolution technique borrowed and modified (Schopf et al., 2006) from its use in detailed morphological studies of the fine-scale internal architecture of modern cells. Although not yet widely adopted by the international Precambrian paleobiological community primarily because few scientific journals provide means for the incorporation of the rotating three-dimensional video images provided by CLSM - the instrument used for such studies is readily available in many university biology departments. CLSM is a highly effective research tool and the only technique now available for complete morphological investigation of minute fossils rock-embedded at depth, permitting their images to be rotated parallel to the thin section surface and thus viewed from multiple perspectives.

Applied in tandem, these techniques provide unprecedented opportunity to document the intracellular structure of kerogenous microscopic fossils (Figure 9), their indigenousness to and syngenicity with the fossil-hosting mineral matrix, their biogenicity-indicating molecular and isotopic kerogenous composition and three-dimensional form, and their degree of geochemical maturity, all at submicron spatial resolution.

\section{Applications to Megascopic Body Fossils}

Many of these techniques initially designed for studies of minute Precambrian fossil microbes have been applied as well to early-evolved multicellular organisms. A good example is their use in investigations of Eocyathispongia, the earliest fossil sponge now known, reported in 2015 from the Ediacaran Doushantuo Formation of Guizhou Province in southwestern China (Yin et al., 2015). This richly fossiliferous unit, well known to the paleontological community, is actively mined for its economically important phosphate. However, and although much of the diverse Doushantuo biota is thus permineralized in phosphatic fluorapatite, this earliest known fossil sponge is embedded in non-phosphatic limestone. To fully analyze the fossil, the investigating scientists therefore used hydrochloric acid to dissolve the enclosing carbonate matrix and liberate the organic-walled fossil - an example of the application of the acid maceration technique pioneered for Precambrian studies by Timofeev and Hermann - and analyzed its inner wall submicron sponge-distinctive morphology by scanning electron microscopy.

Other of the techniques initially devised for the analysis of Precambrian microfossils have similarly been applied to ancient megafossils. A prime example is the late-stage embryo of a ctenophore coelenterate ("comb jelly") from the basal Cambrian Meishucun fossil assemblage of Shaanxi Province China reputed to contain the oldest complex skeletonized organisms known in the geological record. In this case, the fine structure of the specimen was documented by confocal laser scanning microscopy and shown by Raman spectroscopy to be composed of carbonaceous kerogen permineralized in apatite (Chen et al., 2007). Additional examples could be cited, but these two, the oldest known fossil sponge and oldest known comb jelly, are sufficient to prove the point. Clearly, the techniques devised for the study of microscopic Precambrian life have applicability to megafossils as well.

\section{INTERNATIONAL INTERDISCIPLINARITY}

One additional aspect of the study of Precambrian life remains to be addressed, namely its distinctive international interdisciplinary character, a hallmark of the science introduced early in its modern development that has led to its marked success over the past half-century.

In the 1960's as seminal findings laid the groundwork for the field, international interdisciplinary science was far from the norm. Internationalism had been repeatedly thwarted by geopolitical strife and interdisciplinary science was generally discounted, the assumption being that adherents of this approach were likely to be "jacks of all trades but masters of none." Quite clearly, that does not apply to practioners of Precambrian paleobiology today. It is thus germane to inquire how the current mindset originated, what are its roots? The following discussion will help to answer this question and elucidate how interdisciplinary studies of Precambrian life have risen to their current global status.

In 1978, using prize money provided the United States National Science Board's 1977 Alan T. Waterman Award I 


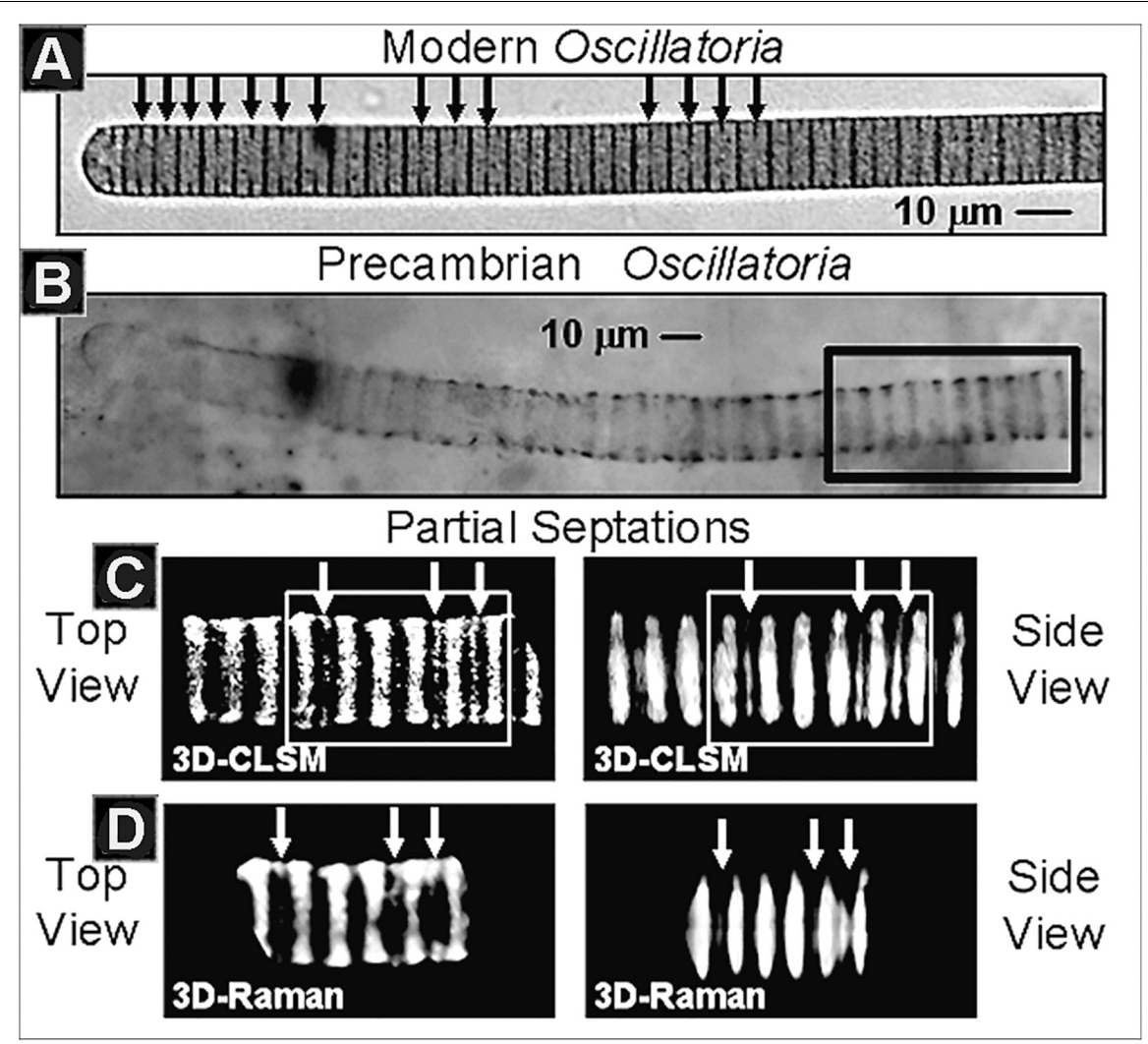

FIGURE 9 | (A) The modern cyanobacterium Oscillatoria, denoting (black arrows) its intracellular partial septations, the precursors of subsequent cells walls and cellular binary division. (B) Optical photomicrograph of fossil Oscillatoria persevered in carbonaceous stromatolitic chert of the Neoproterozoic $~ 750$ Ma Chichkan Formation of South Kazakhstan, denoting the region (black rectangle) depicted in the CSM and Raman images immediately below. (C) Three-dimensional CLSM images of the Chulaktau fossil in top and side views, denoting its partial septations (white arrows). (D) Three-dimensional Raman images of the same region of the fossil in top and side views, denoting the same partial septations (white arrows).

elected to establish the Precambrian Paleobiology Research Group (PPRG), an effort to promote the advancement of the science and lay a framework for its further development. Unfortunately, however, the monies available were insufficient to fund the planned 14-month stay of the envisioned international interdisciplinary team of "Young Turks" and their families at UCLA. Matching funds were therefore sought from NASA's Exobiology Program, a proposal that was reviewed and immediately rejected by the two leading experienced specialists in the field, Elso Barghoorn (because "science is done by individuals, not by groups") and Preston Cloud (because "the group lacks senior leadership"). Despite the negative assessments of these luminaries, the proposal was funded.

This first version of the PPRG included 19 members from four counties, Australia, Canada, Germany and the United States. Included in its ranks were established and up-and-coming workers focused on Earth's formative Hadean development, prebiotic organic syntheses, Archean geology, organic and isotopic geochemistry, microbiology, Archean microfossils and stromatolites, and Archean atmospheric and environmental evolution. The group pooled its rock collections, carried out laboratory research together as a team, and each Wednesday evening became educated about the specialty of one of the other members. The product of this venture, Earth's Earliest Biosphere, its Origin and Evolution (Schopf(ed.), 1983), was published In 1983, an extensive 543-page tome presenting new research results and summarizing the interrelated biologic-environmental evolution of the earliest two billion years of Earth history.

Given the success of this Hadean-Archean-focused project, in 1984 I set in place its sequel, this time adding participants from Denmark, South Africa, Sweden and the USSR and increasing the roster to include a total of 42 members incorporating workers having expertise in the 2.5-0.5 Ga Proterozoic segment of Precambrian biotic and environmental Earth history. Again carrying out international field expeditions (generously funded by the National Geographic Society) and working together at UCLA for a 14-month period, in 1992 the product of this second PPRG study was published, The Proterozoic Biosphere, A Multidisciplinary Study (Schopf and Klein, 1992), a mammoth 1,348-page volume.

This second study, like its predecessor, had considerable impact on the development of the field. Each of the volumes produced received the Association of American Publishers' Professional and Scholarly Publishing Award in its year of publication and virtually all of the participants in the two PPRG ventures continued on to become acknowledged leaders in the 
science, some two-thirds of the members having been elected to their country's national academy of science. Moreover, and of considerable interest to the broader scientific community, the influence of the international interdisciplinarity of the PPRG continued unabated even after the conclusion of its two-part, almost two-decade-long effort. Indeed, this successful experiment provided the model on which NASA Deputy Director Jerry Soffen based the NASA Astrobiology Institute, in his words designed to be a "virtual PPRG," that has had enormous impact in promoting and advancing the science of astrobiology and establishing the foundation for NASA's current search for evidence of past life on Mars.

\section{PROGRESS}

The developments summarized above - from the breakthrough advances of 1950 to 1965 , to the subsequent decades-long introduction of new analytical techniques, to the international interdisciplinary field-establishing PPRG - set the stage for the science today. What progress has been made?

\section{Oldest Records of Life}

Over the past half-century, the science has prospered, mightily. Spurred by early publications elucidating the mode of formation and abundance of fossil stromatolites (Walter, 1973, Walter, 1977), a great majority of this progress has focused on the Proterozoic (2.5-0.541 Ga) segment of the Precambrian from which many hundreds of stromatolitic and/or microfossiliferous units have been reported. Taken as a whole, life's Proterozoic fossil record is now known to include prokaryotes, acritarchs, testate protists, microscopic problematica, megascopic algae, softbodied metazoans and diverse trace fossils (for comprehensive early summaries of such taxa see Mendelson et al., 1992; Sepkoski and Schopf, 1992; and Towe et al., 1992; and for an up-to-date review of such finds from the 2.5 to $1.6 \mathrm{Ga}$ Paleoproterozoic, see Javaux and Lepot, 2018).

Unsurprisingly, far fewer fossiliferous units are known from the underlying older Archean (4.0-2.5 Ga) segment of the Precambrian, a result of the paucity of such ancient sedimentary rocks that have survived to the present. Estimated to include only about $5 \%$ of the surviving rock record (Garrels and Mackenzie, 1971, pp. 255-276), not only have virtually all originally deposited Archean sediments been geologically recycled but those that have survived, particularly those older than $3.2 \mathrm{Ga}$, have experienced varying degrees of fossil-altering or -destroying metamorphism. Indeed, only three major regions are known to contain appreciable sequences of such Paleoarchean strata, the relatively less metamorphosed Pilbara Craton of northwestern Western Australia, the moderately altered Barberton Mountain Land of South Africa, and the typically rather severely metamorphosed Isua Supracrustal Group and associated units of southwestern Greenland (for a tabulation of fossils reported from these and other Archean units see Tomescu et al., 2016, Table 3.2). Interestingly, given the current and ongoing episode of global warming and the easily predictable continued melting of the Greenland ice sheet, an ever-increasing array of even more ancient potentially fossiliferous strata is likely to become exposed, a promising future source of new evidence of life's earliest history.

Nevertheless, despite the obvious impediments imposed by the metamorphically altered, areally limited Paleoarchean rock record available for study, early records of life are well established - again, not surprisingly, from the least metamorphosed of the three major Paleoarchean terrains. At present, the oldest widely accepted fossils known are stromatolites of $\sim 3.48 \mathrm{Ga}$ Dresser Formation of the northwestern Australian Pilbara Craton (Van Kranendonk et al., 2021). Although devoid of preserved stromatolite-forming microorganisms, the abundance, distinctive laminar fabric, hot springs setting, and comparability of these stromatolites both to modern examples and to fossil specimens occurring in similarly Paleoarchean units leave little doubt as to their biogenicity.

Moreover, the Dresser stromatolites are only slightly older than the oldest diverse fossil microbiota now known, that of the $\sim 3.465 \mathrm{Ga}$ Apex chert, also of the Pilbara Craton. First reported nearly 30 years ago (Schopf, 1993), the 11 taxa described from the partially degraded primarily filamentous microbial assemblage on the bases of measurements of nearly 1,900 cells ranging from 0.5 to $19.5 \mu \mathrm{m}$ in diameter preserved in 173 specimens, have stood the test of time (Figure 10). Over the ensuing years, the indigenousness, syngenicity and biogenicity of the Apex fossils - including their organismal morphology, cellularity and carbonaceous composition and kerogenous molecular structure - have been repeatedly established at submicron spatial resolution by optical microscopy, photomontage, TEM, Raman spectrometry and CLSM, making this the most thoroughly investigated fossil microbiota known from the geological record. In addition, and perhaps of even greater significance, the biologic affinities of five of the 11 taxa have recently been documented by SIMS (Schopf et al., 2018) showing the assemblage to include anoxygenic photosynthetic bacteria and both anaerobic methane-producing and anaerobic methane-consuming archaea. All three of these lineages are situated near the base of the rRNA phylogenic Tree of Life, their documentation in this oldest known diverse biota thus reinforcing the credibility of Precambrian microfossil studies, of molecular biologic phylogenetic analyses of the extant counterparts of ancient microbes, and of geochemistry-based inferences of the low oxygen content of the Paleoarchean environment.

In sum, as Precambrian paleobiology has matured over the past half-century, workers worldwide have amassed a voluminous body of telling evidence, even from the relatively sparse Archean rock record. Included among the particularly ancient examples are well more than a score of reports of stromatolites and cellular microbial fossils dating from earlier than $3.2 \mathrm{Ga}$ (those from the Barberton Mountain Land recently reviewed by Homann, 2019) and SIMS analyses of the carbon isotopic composition of possibly biogenic graphite in pre-3.5 Ga zircons (Bell et al., 2014, 2015; Tang et al., 2019). Among all these, the diverse microbial assemblage of the Apex chert stands out as a definitive benchmark, the most thoroughly scrutinized, evaluated and repeatedly affirmed finding in the history of the science. Taken as a whole, such evidence not only resolves Darwin's dilemma, extending the known fossil record by a remarkable sevenfold 


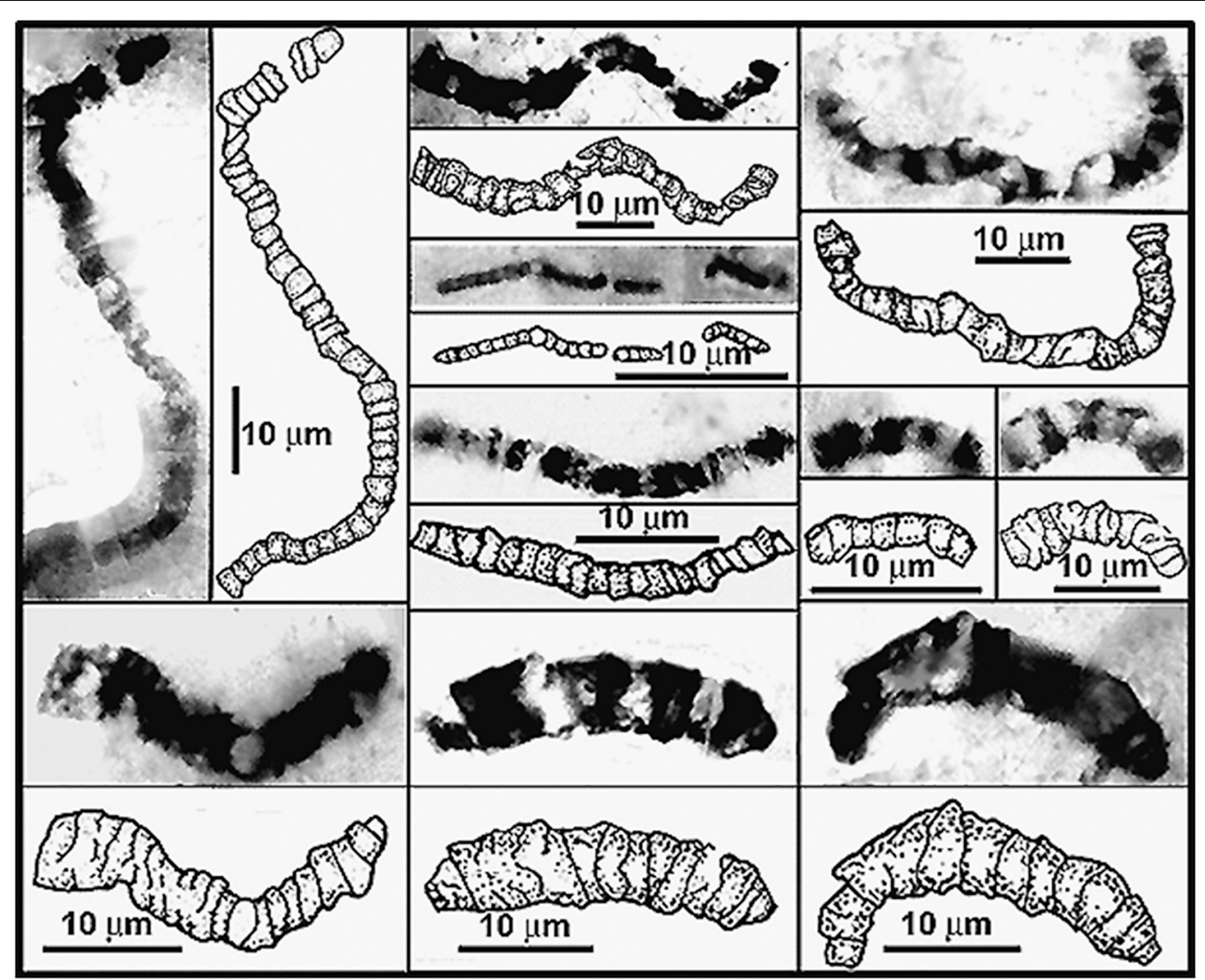

FIGURE 10 | Representative filamentous microfossils from the Paleoarchean $\sim 3,465$ Ma Apex chert of northwestern Western Australia.

from that known when The Origin first appeared, but it establishes as well that primordial life evolved early, far and fast a largely unexpected, and thus rather remarkable insight into life's earliest development.

\section{Mid-Precambrian Origin of Eukaryotes}

Recognition of the occurrence of a mid-Precambrian significant increase of global environmental oxygen - the great oxidation event, "GOE," biotically important as providing the abundance of oxygen necessary to fuel biologic obligate aerobic respiration dates from the geological-paleoenvironmental studies of $\mathrm{H}$. D. Holland (2006). His postulate was based on analyses of the temporal distribution of banded iron formations, globally widespread deposits typified by cyclically repeating alternating bands of fine-grained hematite $\left(\mathrm{Fe}_{2} \mathrm{O}_{3}\right)$ and iron-deficient layers of fine-grained chert that provide the foundation of the world's steel industry (Figure 11). Holland found that many such deposits were situated in the shallow portions of inland seas and that they spanned the time from about 3.0 to $2.0 \mathrm{Ga}$ ago, rising slowly in abundance to a peak at about $2.5 \mathrm{Ga}$ and then gradually petering out. Reasoning that their banded character reflected seasonal changes, he postulated that their cyclicty reflected the yearly upwelling of ferrous iron from deep-sea volcanic fumaroles and that the environmental oxygen required for deposition of their distinctive oxidized hematitic bands was a result of cyanobacterial oxygenic photosynthesis.

Resulting from the studies of M. H. Thiemens, who was first to investigate the mass-independent fractionation (MIF) of oxygen (Thiemens and Heidenreich, 1983) and subsequent studies of the MIF of sulfur by Thiemens' student J. Farquhar, the date of the GOE was more precisely set at $\sim 2.3 \mathrm{Ga}$ (Farquhar et al., 2000). The data are convincing. Mass-independent fractionation of sulfur isotopes in Archean sediments is a strong indicator of an anoxic Archean atmosphere, substantiated by numerous independent lines of evidence, and the MIF of sulfur isotopes is known in numerous sediments of the Archean and early Proterozoic but not in rocks younger than $\sim 2.3 \mathrm{Ga}$. This is not to imply, however, that Earth's atmosphere became "fully oxygenated" at $2.3 \mathrm{Ga}$. Indeed, current estimates indicate that permanent oxygenation was not attained until $\sim 2.2 \mathrm{Ga}, 100 \mathrm{Ma}$ later (Poulton et al., 2021), and even then remained at low concentrations, far below current atmospheric levels, for the following billion years or more (Olson et al., 2018).

Independent of these important breakthroughs, Precambrian paleobiologists had previously noted the presence in Paleoproterozoic deposits $\sim 2.1 \mathrm{Ga}$ and younger of largecelled spheroidal phytoplankton, far too large to be comparable to extant prokaryotes. There was thus no doubt that these 


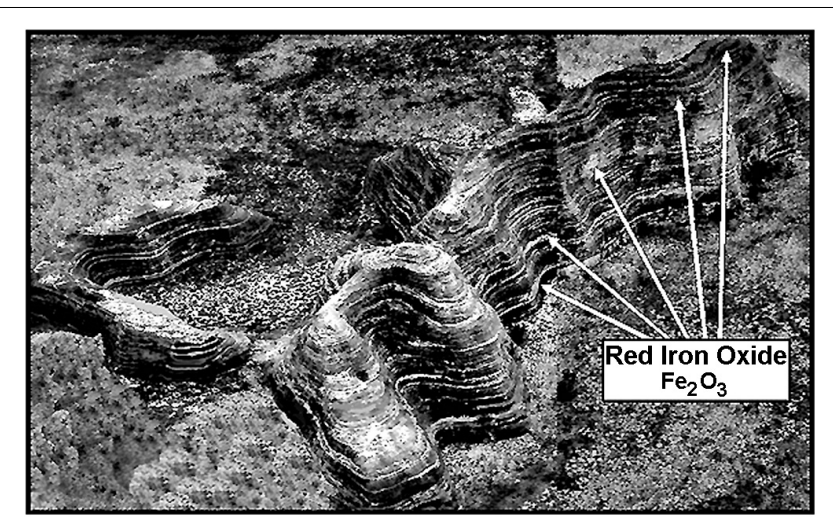

FIGURE 11 | Aerial photograph showing an outcrop of one of the several mid-Precambrian 2,500 Ma banded iron formations in the Hamersley Basin of northwestern Western Australia.

megasphaeromorphs were unicellular algal eukaryotes, not prokaryotes, but because their precise affinities to modern algal groups were uncertain they were collectively grouped together in the taxonomically non-committal “Acritarcha”(Evitt, 1963), taxa of which are known today from many Proterozoic and Phanerozoic deposits (Knoll, 1992; Colbath and Grenfell, 1995; Tomescu et al., 2016, Table 3.3).

Because all eukaryotes are oxygen-dependent, the geochemical-paleoecological MIF data and the post-GOE fossil evidence mesh together, the advent of eukaryotes being enabled by the increase of environmental oxygen. This sequential co-occurrence seems well established. The MIF-indicated $\sim 2.3 \mathrm{Ga}$ date of the onset of the GOE is holding firm. Acritarchs are well documented in the Paleoproterozoic (Figure 12), including the $\sim 1631 \mathrm{Ma}$ (Ray et al., 2002). Deonar Formation of Madhya Pradesh, India (Prasad et al., 2005), the $\sim 1,650 \mathrm{Ma}$ Changzhougou Formation of North China (Miaoa et al., 2019) and the $\sim 1650$ Ma Mallapunyah Formation of northern Australia (Javaux et al., 2004). Similarly, $>300 \mu \mathrm{m}$-diameter specimens of the sphaeromorph acritarch Leiosphaeridia occur in the $\sim 1.9 \mathrm{Ga}$ Kondopoga Formation of Karelia, Russia (Javaux and Lepot, 2018) and even older sphaeromorphs - including Leiosphaeridia, Dictyosphaera, Dongyesphaera, and Satka - have been recorded from the $\sim 2,090 \mathrm{Ma}$ (Wilde et al., 2004) Hutuo Group of Shanxi Province in northern China (Yin et al., 2020).

With regard to larger putatively eukaryotic algal fossils, two particularly ancient examples can be noted. Thin, wedge- and tongue-shaped compressions up to $18 \mathrm{~cm}$ long and $4 \mathrm{~cm}$ broad, some longitudinally striated or having possible basal holdfasts, have been reported from the 1,560 Ma Mesoproterozoic Goayuzhuang Formation of northern China (Zhu et al., 2016). Although assuredly thallus-like and thus presumably remnants of multicellular eukaryotic algae, the available evidence is insufficient to firmly establish their biological relationships. The second example is of even more uncertain affinities. One to two millimeter-broad specimens of the coiled strand-like macrofossil Grypania have been recorded from the $\sim 1,890 \mathrm{Ma}$ (Pietrzak-Renaud and Davis, 2014) Paleoproterozoic Negaunee

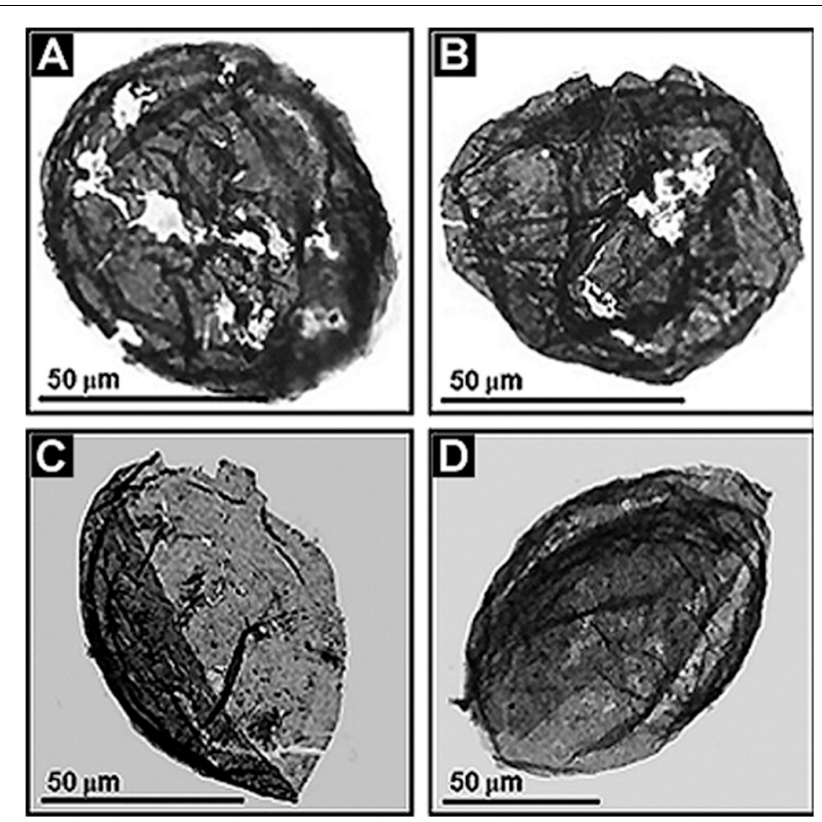

FIGURE 12 | (A-D) Paleoproterozoic acritarchs, large-celled spheroidal and ellipsoidal eukaryotic phytoplanktonic fossils from the $\sim 1,800 \mathrm{Ma}$ Changzhougou Formation of the Yanshan Mountain Range, North China.

Iron Formation of northern Michigan, United States (Han and Runnegar, 1992). Although previously regarded by Runnegar (1994) to be a chlorophycean green alga, other workers have backed away from this assessment, regarding Grypania to be a eukaryote of undetermined affinities (Knoll et al., 2006) or, more recently, as representing either a eukaryote or possibly a largesize prokaryote, a fossil thus classed as Incertae Sedis (Sharma and Shukla, 2009a,b).

Thus, taken as a whole - the established record of Paleoproterozoic acritarch microfossils and the reports of plausible, if as yet unsubstantiated mid- to possibly earlyProterozoic algal macrofossils - affirm the mid-Precambrian origin of eukaryotic life. This second major feature of life's Precambrian history, the timing and GOE-related paleoenvironmental impetus for the origin of eukaryotic cells, seems well established.

\section{Late Precambrian Advent of Eukaryotic Sexuality}

Progress has also been made in defining the time of origin of a third great advance in life's Precambrian evolutionary development, the advent of eukaryotic sexuality.

Beginning with the origin of single-celled eukaryotic acritarchs about $2.1 \mathrm{Ga}$, biotic evolution appears to have stalled, virtually shutting down for the following billion or so years, in retrospect a striking anomaly given the subsequent Neoproterozoic rapid rise in eukaryotic diversity and abundance. And not only did biotic advance seemingly grind to a halt, but major global geological and climatic change seem also to have markedly quieted, prompting this ensuing period of stasis to 
have been described as "the dullest time in Earth's history" (Buick et al., 1995), the "boring billion"(Brasier, 2012).

In retrospect, it is notable that this long-term stasis of biological evolution, at least among ancient prokaryotic microorganisms, was not unexpected. As early as the detailed descriptions of the stromatolitic $\sim 850$ Ma Bitter Springs microflora (Schopf, 1968; Schopf and Blacic, 1971) it had been recognized that many types of Precambrian prokaryotic cyanobacteria are essentially indistinguishable from modern counterpart genera and even species. This marked morphological comparability, in concert with evidence of virtually identical fossil-modern developmental life cycles, was soon established by a great many workers worldwide for fossil cyanobacteria in innumerable Proterozoic stromatolitic assemblages. Such similarity is well illustrated by the common practice of naming newly discovered fossil taxa by adding the prefixes "archaeo-" (ancient), "paleo-" (old) or "eo-" (early), or the suffix "-opsis" (resembling) to the genus name of a modern cyanobacterial generic name to highlight the apparent identity of the fossil and modern analogs. Indeed, a recent compilation of such taxa from a mere seven Proterozoic deposits lists some 21 such fossil-modern namesake taxa (Schirrmeister et al., 2016).

Ultimately, after 25 years and the repeated confirmation of this remarkably slow rate of prokaryotic evolutionary change, it was codified as "hypobradytely" (Schopf, 1994), literally, the "slowest of the slow" referring to a taxon longevity of $\pm 1,000 \mathrm{Ma}$. This seemingly arcane term was coined to parallel Simpson's (1944) fossil-record established rate-distributions of Phanerozoic taxa: "tachytelic" (fast evolving short-lived species having a longevity of $\pm 1 \mathrm{Ma}$ ), "horotelic" (typical species having lifetimes of $\pm 10 \mathrm{Ma}$ ) and "bradytelic" (long-lived species, having a longevity of $\pm 100 \mathrm{Ma}$ ). It is important to note, however, that prokaryotic hypobradytely does not imply that such microbes did not evolve. They certainly did, not morphologically but biochemically as they slowly adapted to gradual, virtually imperceptible changes in oxygen availability, day-length, UV-flux, salinity and other aspects of their environment.

In contrast with such hypobradytelic prokaryotic evolutionary stasis, about 1 billion years ago eukaryotic acritarchs began to markedly increase in abundance, diversity, size, complexity of shape, and especially the size and number of their surficial spines, a development first documented by Timofeev and Hermann (1979; Figure 13). These evolutionary advances were soon paralleled by the appearance of testate protozoans (Schopf et al., 1973a; Bloeser et al., 1977), diverse multicellular algae (Xiao et al., 2004) and filamentous fungi (Butterfield, 2005; Kolosov, 2016), a series of accelerating advances well summarized by Knoll (1994); Knoll et al. (2006), and Butterfield (2014). What is this basis of this late Precambrian dramatic surge in biotic diversity and evolutionary rate?

A plausible explanation was first suggested in 1973 in a paper noting that prokaryotes - whether unicellular, colonial, or multicellular and filamentous - are uniformly asexual, reproducing by binary division, a "cloning" of their cells, their genetic components being passed to subsequent generations unchanged except for random mutations. The paper went on to point out that that this prokaryotic mode of reproduction

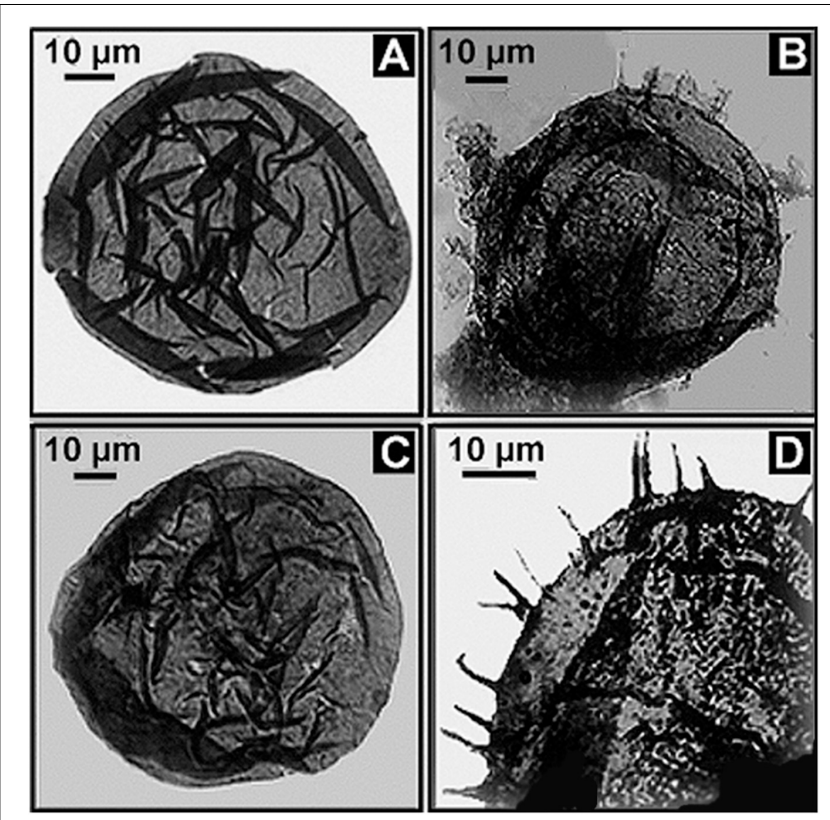

FIGURE 13 | (A,C) Fossil eukaryotic phytoplanktonic acritarchs from the $\sim 1,020 \mathrm{Ma}$ Lakhanda Formation of southeastern Siberia, the spheroidal acritarch Kildinella $(\mathbf{A}, \mathbf{C})$ and the spiny acritarch Trachyhystrichosphaera $\mathbf{( B , D )}$.

differs markedly from the sexual reproduction characteristic of eukaryotes, a process that combines the genetic information from two differing parental stocks to produce offspring that (except for identical siblings) differ one from another. Reasoning that increased genetic diversity would result in increases in adaptation to diverse environments and, thus, of biotic diversity, biotic interactions and evolutionary rates, the paper proposed that the origin of eukaryotic sexuality presented a plausible explanation for the rise of late Precambrian eukaryotic life (Schopf et al., 1973b).

Based on the foregoing, the origin of eukaryotic sexuality at $\sim 1$ Ga was pegged as the cause of the now firmly established rise in the rate of change and biotic diversity of Neoproterozoic life, another "old idea" that seems to have withstood the test of time.

Note, however, that somewhat older evidently sexually reproducing eukaryotes are now known, in particular the $\sim 1,198$ Ma red alga Bangiomorpha pubsecens of the Hunting Formation of Arctic Canada (Butterfield, 2000) - the red algal affinities of which are not unexpected given that that this clade is generally regarded to be the phylogenetically most closely allied of all algal groups to their asexual photosynthesizing cyanobacterial precursors. Moreover, if the origin of eukaryotic sexuality is the correct explanation for the change in rate and marked increase of biotic diversity of Neoproterozoic life, it implies that earlier evolving acritarchs and the few other particularly ancient possible eukaryotes now known were asexual and that the development of sexual reproduction did not occur until a billion years after the eukaryotic lineage originated. Though this is not implausible, such modern eukaryotic green algae as Chlorococcus, Chlorella, and Chlorococcum being entirely 
asexual, the mode of reproduction of pre-1.2 Ga eukaryotes has yet to be documented.

Thus, the question posed by the Neoproterozoic surge of biotic diversification and evolutionary rate seems answered, at least for the present, with much remaining to be learned from the fossil record about the transition from asexual to sexual reproduction and the biotic impact of the rise in atmospheric oxygen content that would surely have accompanied the sex-derived proliferation and diversification of $\mathrm{O}_{2}$-producing phototrophs. Evidently, the preceding so-called "boring billion" was paleobiologically not so boring after all.

\section{PROSPECTS}

Numerous major questions about life's early history remain unanswered. Some are obvious, some less so, unknowns quite effectively posed by Javaux (2019). The following is a synopsis of five such topics, temporally ranging from the Paleoarchean to the Neoproterozoic, quandaries for which viable solutions would greatly advance the field.

\section{Missing Evidence of the Life-Generating "Primordial Soup"}

In the 1920's, A. I. Oparin (1924) and J. B. S. Haldane (1929) independently hypothesized that life originated from a "primordial soup" produced abiotically in Earth's early anoxic environment. A quarter-century later, in the 1950's, this concept was shown to be plausible by the laboratory syntheses of abiotic organics under pre-biotic conditions by Miller (1953) and his mentor, H. C. Urey (Miller and Urey, 1959). Nevertheless, and although widely accepted by the scientific community, the Oparin-Haldane hypothesis has yet to be confirmed by direct evidence from the geological record establishing the existence of the postulated life-generating abiotic broth.

At first glance, this absence of evidence seems surprising. After all, Miller-Urey-type syntheses have been studied for many decades and found to generate an enormous array of biologically important organic compounds (amino acids, sugars, monomers of nucleic acids and many others). Moreover, such syntheses are primarily inhibited only by the presence of molecular oxygen, shown by paleoenvironmental studies to have been absent or present in only trace concentrations until $\sim 2.3 \mathrm{Ga}$ ago. Given this, it might well be imagined that evidence of residual remnants of the primordial abiotic soup should exist in the sedimentary rock record throughout the Archean and into the earliest Paleoproterozoic.

Placed in context, however, the lack of evidence of such abiotic organics in the rock record can be easily explained. Sedimentary carbonaceous matter, "kerogen" - for example that of coal, black shales and fossiliferous black cherts - is derived from buried partially decayed remnants of previously living systems. Once life had originated and proliferated, the biota became a far more voluminous producer of organics than relatively inefficient abiotic syntheses. Thus, even if abiotic organic matter is present in the sedimentary rock record up to early Proterozoic, it would be virtually undetectable, "swamped out" at a ratio of hundreds of thousands to one by the organics produced by life.

Thus, in the absence of the pre- 4.0 Ga Hadean sedimentary rock record which would have harbored evidence of a prelife stage in Earth's development, the search for remnants of the primordial soup resolves into a proverbial "needle in a haystack hunt." But success is not out of the question. Stemming from the seminal studies of Abelson and Hoering (1961), the preservation in sedimentary kerogens of the stable isotopes of carbon, ${ }^{12} \mathrm{C}$ and ${ }^{13} \mathrm{C}$, has been long established, their relative abundance being a function of enzyme-mediated biological mass-dependent kinetic isotopic fractionation. Documented in thousands of kerogenous Phanerozoic and Precambrian sediments, data from the Phanerozoic generated largely by the petroleum industry in their search for productive oil reservoirs, carbon isotopic ratios have been used to trace the record of biologic photosynthesis, whether $\mathrm{O}_{2}$-producing or anoxygenic, to $\sim 3.5 \mathrm{Ga}$ (Schidlowski et al., 1983), an assessment later up-dated to $\sim 3.8 \mathrm{Ga}$ (Schidlowski, 1991).

Kerogens, however, are geochemically altered remnants of originally deposited organics which, as they mature toward their lasting endpoint, graphite, become increasingly modified into increasingly larger aggregates of geochemically stable plate-like polycyclic aromatic hydrocarbons (PAHs). As a result, much of their original enzyme-determined detailed molecular structure is destroyed. Nevertheless, in relatively less mature kerogens, unaltered molecular bridges link such PAHs together and it is here that residuums of the abiotic soup might be detected.

As demonstrated by the pioneering studies of J. M. Hayes (reviewed in Hayes, 2001), the intramolecular distribution of the stable isotopes of carbon and hydrogen in biosynthesized organic matter is, like the isotopic properties of bulk samples of carbonaceous kerogen, a result of enzymatic synthesis with such products having a regular distribution of ${ }^{12} \mathrm{C}$ and ${ }^{13} \mathrm{C}$, and ${ }^{1} \mathrm{H}$ and ${ }^{2} \mathrm{H}$ atoms. In contrast, the products of Miller-Urey and all other types of abiotic syntheses are composed of randomly distributed carbon and hydrogen atoms. Thus, the intramolecular carbon and hydrogen isotopic distribution in the linkage groups of kerogenous PAHs seems a promising source of data by which to distinguish biotic and abiotic carbonaceous sedimentary organic matter. Though the abiotic signal can be expected to be small, it might well be discernable and, thus, provide telling evidence of the hypothesized non-biological production of organic matter early in Earth history.

\section{Timing of the Origin of Oxygenic Photosynthesis}

As noted above, stromatolite-, microfossil-, and carbon isotopicevidence of biological photosynthesis extend to at least $\sim 3.5 \mathrm{Ga}$. But a cardinal question remains unanswered, namely, when did oxygen-producing cyanobacteria evolve from their anoxygenic bacterial ancestors, an important precursor to subsequent biotic evolution including the early Proterozoic development of oxygen-dependent eukaryotes.

Although the uppermost surface of modern stromatolites both of lithified and unlithified mat-forming microbial 
communities - is occupied by $\mathrm{O}_{2}$-producing cyanobacteria, the $\sim 3.5 \mathrm{Ga}$ presence of stromatolites (Van Kranendonk et al., 2021) does not solve the problem. Formed by communities of mobile phototrophs as they spread across surfaces to absorb light, modern microbial mats include a thin anoxic zone directly beneath the cyanobacterial layer that is inhabited by anoxygenic photosynthetic bacteria, primarily green sulfur bacteria such as Chlorobium and purple sulfur bacteria such as Thiospirillum (Figure 14). These and other co-occurring non- $\mathrm{O}_{2}$-producing photosynthesizers are able to "see through" the overlying layer and power their photosynthesis by absorbing parts of the solar spectrum not absorbed by cyanobacterial chlorophyll (Figure 15). Thus, prior to the advent of oxygenic cyanobacteria, anoxygenic photosynthetic bacteria would be expected to have formed stromatolites morphologically similar to those dominated by cyanobacteria, with such microbial non-oxygen producers known to have been existed at least as early as $\sim 3.5 \mathrm{Ga}$ (Schopf et al., 2018).

Given the foregoing, the quandary posed regarding the time of origin of $\mathrm{O}_{2}$-producing photosynthesis resolves to the problem of distinguishing between the preserved cellular remnants of early-evolved anoxic and oxygenic microbial phototrophs, the search centered in the Paleoarchean when the rock record, though scant and metamorphically altered, still exists. Unfortunately, however, this problem is compounded by the morphological similarity between members of the two groups, bacteriochlorophyll-containing anoxygenic photosynthetic bacteria being evolutionary precursors of biochemically modified chlorophyll-containing oxygen-producing cyanobacteria. Indeed, members of the two groups are primarily distinguished not by their morphology but by the terminal reductant used in their differing types of photosynthesis, hydrogen sulfide for the anoxygenic bacterial photosynthesizers - rather than water, as for the cyanobacteria - and, hence, by the byproducts produced, elemental sulfur for the non-oxygen producers instead of the molecular oxygen of cyanobacteria.

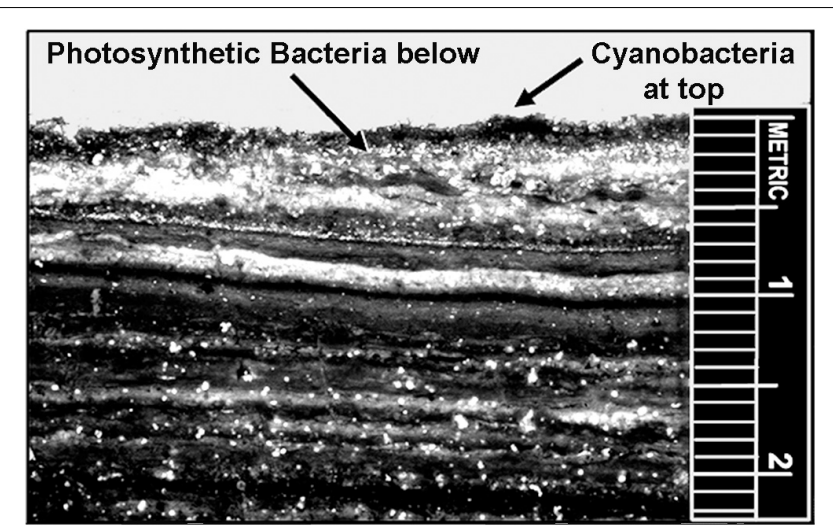

FIGURE 14 | Modern microbial mat community from Laguna Mormona, Baja Mexico showing the layered distribution of oxygenic cyanobacteria, at the top, the immediately underlying zone of anoxygenic photosynthetic bacteria, and the numerous lower anaerobic layers that evidence earlier stages of the mat community's development.
This difference in the byproducts of the two processes presents a potential means to address this conundrum. Elemental sulfur is geologically short-lived and in the anoxic Paleoarchean environment would have been especially so, reacting with ferrous iron to form pyrite as is well established for a $\sim 3.4$ Ga sulfurcycling microbial sulfuretum recently reported from the $\sim 3.4 \mathrm{Ga}$ Strelley Pool Formation of the Pilbara Craton (Schopf et al., 2017). As this study shows, the characteristic seemingly random "cobweb-like" fabric such sulfur-cycling consortia is easily distinguishable from the well-laminated phototroph-formed fabric of stromatolites. Nevertheless, because the metabolic cycle of such sulfuretums involves the production of elemental sulfur, like that generated by anoxygenic photosynthesis, this fossilized assemblage contains copious amounts of microgranular pyrite. From this it would follow that stromatolites produced by solely anoxic photosynthetic bacteria might contain appreciable concentrations of fine-grained $(<1 \mu \mathrm{m}$-sized) pyrite, as a cursory perusal of relevant specimens and the literature seems to suggest, the presence and then relative absence of such grains centering at about $3.0 \mathrm{Ga}$. Clearly, detailed in-depth investigation of this supposition or some more telling solution will be needed to properly pin down the time of origin of oxygenproducing photosynthesis.

\section{Long-Term Secular Environmental Change}

Stemming from their pioneering studies of the paleotemperatureindicating ratios of the stable ${ }^{16} \mathrm{O}$ to ${ }^{18} \mathrm{O}$ isotopes in the $\mathrm{SiO}_{2}$ of Precambrian cherts, Knauth and Lowe (1978, 2003) and Knauth (2005) postulated that Earth's surface temperature decreased over geological time to its present $\sim 15^{\circ} \mathrm{C}$ from a high of $70^{\circ} \pm 15^{\circ} \mathrm{C}$ during the Paleoarchean. Soon thereafter, this inference was reinforced by analyses of the stable ${ }^{29} \mathrm{Si}$ to ${ }^{30} \mathrm{Si}$ isotopes of silicon in cherts (Robert and Chaussidon, 2006). These interpretations, however, have been much contested due to uncertainties associated with possible changes in oceanic isotopic compositions (Perry, 1967; Kasting et al., 2006; Hren et al., 2009) and age-related diagenetic and/or metamorphic resetting of the reported isotopic signatures (Degens and Epstein, 1962; Weis and Wasserburg, 1987; Chakrabarti et al., 2012).

What was needed to resolve these ambiguities was a different line of evidence, one wholly independent of the isotopic ratios of cherts. A possible solution emerged, stimulated by the groundbreaking studies of Akihiko Yamagishi and his colleagues at the Tokyo University of Pharmacy and Life Science who pioneered the reconstruction of ancient enzymes to unravel the potentially telling data encoded in their original compositions. The success of this approach was demonstrated in 1998 when Yamagishi and his team used the reconstructed enzymes of the phylogenetically inferred last universal common ancestor of life, "LUCA," to suggest it to have been a thermophile (Yamagishi et al., 1998). To follow this lead, UCLA graduate student Amanda Garcia spent two extensive stays in Yamagishi's Tokyo lab investigating temperature-indicative reconstructed enzymes of photic-zone inhabiting modern photoautotrophs having fossilrecord established times of phylogenic divergence. 


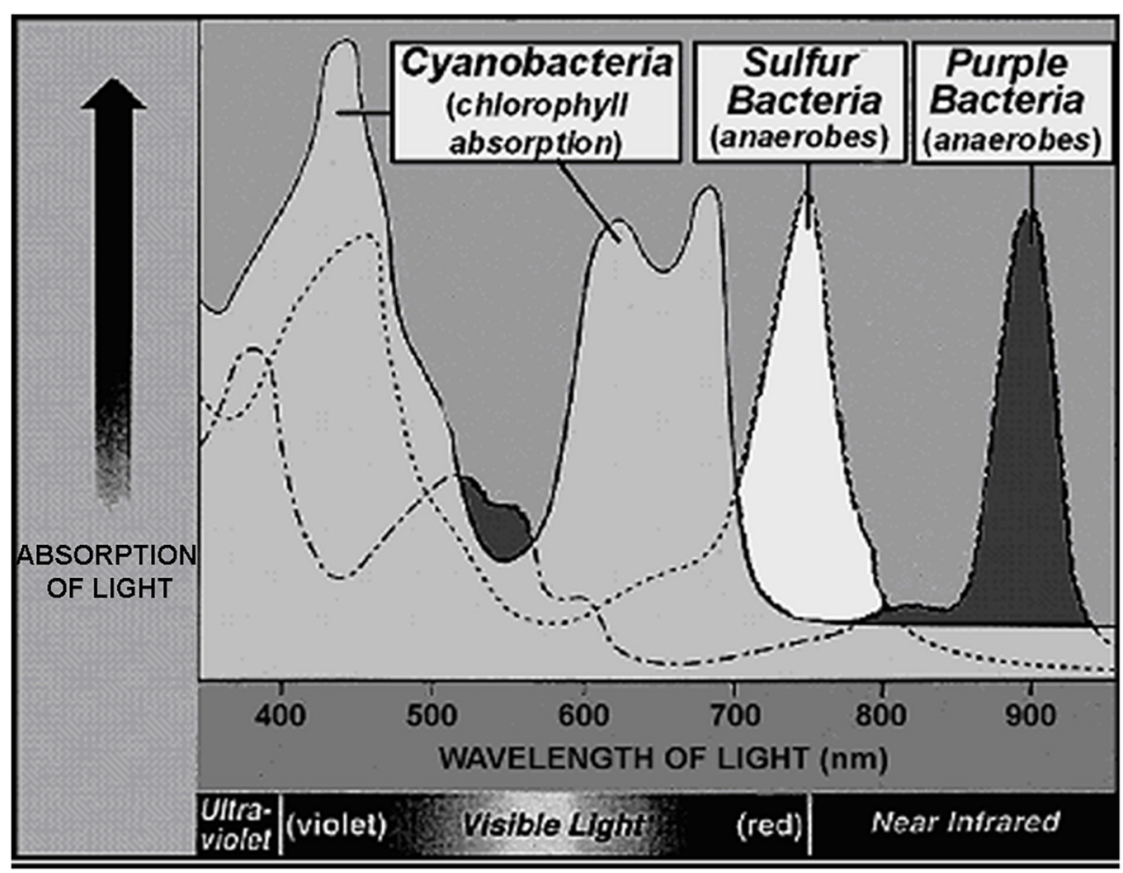

FIGURE 15 | Absorption spectrum comparing the wavelengths of light absorbed by the chlorophyll of cyanobacteria, the surface-inhabitants of modern microbial mat communities, and those of the bacteriochlorphylls of the immediately underlying green and purple sulfur bacteria.

The biomolecule selected to be reconstructed for the resulting study (Garcia et al., 2017) was nucleoside diphosphate kinase, "NDK," an enzyme virtually ubiquitous among extant organisms for which the thermostability had been shown to correlate strongly with organismal growth temperature (Akanuma et al., 2013, 2015). Measurements were made of the thermostabilities of reconstructed ancestral NDK from photic-zone-limited earlyand later-evolving cyanobacteria, green algae, and land plants, groups and subgroups of which have temporally widely spaced fossil-record-indicated divergence ages. Notably, the results obtained, consonant with the previous chert isotope-based studies, indicated a cooling of Earth's surface temperature from $\sim 75^{\circ} \mathrm{C}$ in the Archean $(\sim 3.0 \mathrm{Ga})$ to $\sim 35^{\circ} \mathrm{C}$ in the Devonian $(\sim 420 \mathrm{Ma})$ and a finding consistent as well with other such studies of reconstructed biomolecules (Gaucher et al., 2008; Risso et al., 2013).

The success of such "proof of concept" studies showing the use of reconstructed biomolecules to resolve uncertainties about long-term environmental change suggests its further application to additional paleobiological questions. For example, changes in day-length over geological time, first elucidated for the Phanerozoic by John Wells' seminal studies of Devonian fossil corals (Wells, 1963) and shown also to apply to fossil and modern brachiopods, have yet to be extended into the Precambrian. Such data would be important to document some $90 \%$ of the history of the temporally evolving Earth-Moon system and, thereby, possible perturbations of this system by early events in the evolution of the Solar System. A solution to this problem might be provided by stripping away evolutionimposed modifications of the circadian rhythm-defining modules of extant phototrophs to reveal their original day-lengthdetermined parameters. Similarly, such analyses in extant organisms of the intracellular DNA-repair mechanisms of the damage induced by UV-radiation, particularly in cyanobacterial and anoxygenic phototrophic bacterial lineages that pre-date the mid-Precambrian GOE and the resulting increase in the UVabsorbing ozone layer, might well document the early evolution of the Sun when it became gradually more luminous and its UVflux decreased by $\sim 30 \%$. In short, many such major questions have yet to be addressed, the use of reconstructed ancient enzymes appearing to provide a promising pathway toward their solution, perhaps augmented by better understanding of the impetus presumably provided by mid-Precambrian increases in environmental oxygen.

\section{Bases of Eukaryotic Sexuality}

As discussed above, the advent of eukaryotic sexuality near the beginning of the Neoproterozoic was evidently one of the foremost advances in the history of life. Nevertheless, given its postulated overriding significance, it is surprising that we know so little about the origins of this game-changing process.

Quite obviously, meiosis, the "reduction division" required for the genesis of sperm and egg, the gametes of sexual reproduction, is an evolutionary derivative of earlier established eukaryotic mitotic body cell division, shown by the shared essentially identical first cell-division stages of the two processes. And it is both plausible and presumably likely that the earliest unicellular phytoplanktonic acritarchs were mitotically reproducing asexual algae like such modern unicellular eukaryotic Chlorococcaleans as Chlorococcus, Chlorella, and Chlorococcum. 
Nevertheless, there is no direct evidence from the fossil record of the timing or even the presence of the process of sexual reproduction, its existence inferred solely from its presumed evolutionary products rather than from the evidence of the process itself. Given that meiotic cell division has been established in permineralized (calcified) Carboniferous seed ferns (Millay and Eggert, 1974) as has the presence of preserved nuclei in similarly fossilized (silicified) Triassic cycads (Gould, 1971) and chert-embedded Neoproterozoic algal unicells (Schopf and Oehler, 1976), it is possible and perhaps likely that meiotically produced gametes could also be preserved, evidence that has yet to be uncovered by paleobiologic studies of Precambrian eukaryotes. Such studies of early evolved life cycles might well be aided by understanding of the biochemical bases of the evolutionary roots of eukaryotic sexuality specifically, of the gametogenesis and syngamy on which it is based - a question as yet little investigated even in modern eukaryotes. The answer obtained might well shed light on the impetus, whether biological or environmental, for the advent of the history of life-altering process of eukaryotic sexual reproduction.

\section{Soft-Bodied Precursors of the Ediacaran Fauna}

The precursors of the large many-celled animals of the Ediacaran Fauna were no doubt soft-bodied and much smaller, so small that their fossil record is yet unknown. Plausible candidates for such pre-Ediacaran animals include nematodes of which the best-known living example is the roundworm Caenorhabditis elegans, a taxon more commonly known simply as C. elegans. Used by biologists since the early 1960's as a "model organism," its genetics are thoroughly defined showing that it shares many genes and gene-defined molecular biochemical pathways with humans and, therefore, has proved to be a useful model for studying human diseases. The bodies of such nematodes are not divided into orderly regular segments - as, for example, are those of the common annelid earthworm Lumbricus - so C. elegans is appreciably more primitive.

\section{REFERENCES}

Abelson, P. H., and Hoering, T. C. (1961). Carbon isotope fractionation in formation of amino acids by photosynthetic organisms. Proc. Natl. Acad. Sci. U.S.A. 47, 623-632. doi: 10.1073/pnas.47.5.623

Akanuma, S., Nakajima, Y., Yokobori, S.-I., Kimura, M., Nemoto, N., Mase, T., et al. (2013). Experimental evidence for the thermophilicity of ancestral life. Proc. Natl. Acad. Sci. U.S.A. 110, 11067-11072. doi: 10.1073/pnas.1308215110

Akanuma, S., Yokobori, S., Nakajima, Y., Bessho, M., and Yamagishi, A. (2015). Robustness of predictions of extremely thermally stable proteins in ancient organisms. Evolution 69, 2954-2962. doi: 10.1111/evo.12779

Awramik, S. M., and Barghoorn, E. S. (1977). The gunflint microbiota. Precambr. Res. 5, 121-142. doi: 10.1016/0301-9268(77)90025-0

Barghoorn, E. S., and Schopf, J. W. (1965). Microorganisms from the late precambrian of Central Australia. Science 150, 337-339. doi: 10.1126/science. 150.3694 .337

Barghoorn, E. S., and Tyler, S. A. (1965). Microorganisms from the gunflint chert. Science 147, 563-577. doi: 10.1126/science.147.3658.563
Roundworms such as C. elegans are small, about one millimeter in length and live in the soil where they survive by feeding on bacteria and similar microscopic fodder. But because they are so tiny they cannot nudge aside stony particles and leave identifiable burrows or trails in their wake as do larger annelid worms. Moreover, their body wall is thin and soft, too fragile to be readily preservable in clastic-dominated sediments. Thus, like all other multicelled precursors of the Ediacarian Fauna, they have no known fossil record. A possible solution to this lack of evidence is, as suggested above for the uncertainties enshrouding the origin of eukaryotic sexuality, intensive paleobiologic investigation of chemical deposited, rather than clastic strata. Such permineralized evidence might well exist, whether of preEdiacaran roundworms or of some other such lineage, but this probability has yet to be fully investigated.

\section{DÉNOUEMENT}

There are, of course, a myriad of other unanswered outstanding questions about life's early history, not least of which is whether or not Earth's early biotic record will prove relevant to the search for evidence of past life on other planets, an assumption exemplified by the hunt for potentially microfossiliferous stromatolites by NASA's current Mars 2020 Mission. Nevertheless, as this review of the roots of Precambrian paleobiologic studies and their progress and prospects illustrates, the field has made great strides over the past half century. The future is bright as the field surges forward to discover more and more about the interrelated evolution of life and its environment over the stupendously long span of Precambrian time, new findings being amassed at an ever-quickening pace as is well exemplified by the following papers in this volume.

\section{AUTHOR CONTRIBUTIONS}

The author confirms being the sole contributor of this work and has approved it for publication.

Bell, E. A., Boehnke, P., Harrison, T. M., and Mao, W. L. (2015). Potentially biogenic carbon preserved in a 4.1 billion-year-old zircon. Proc. Natl. Acad. Sci. U.S.A. 112, 14518-14521. doi: 10.1073/pnas.1517557112

Bell, E. A., Harrison, T. M., Kohl, I. E., and Young, E. D. (2014). Eoarchean crustal evolution of the Jack Hills zircon source and loss of Hadean crust. Geochim. Cosmochim. Acta 146, 27-42. doi: 10.1016/j.gca.2014.09.028

Bloeser, B., Schopf, J. W., Horodyski, R. J., and Breed, W. J. (1977). Chitinozoans from the late precambrian chuar group of the Grand Canyon, Arizona. Science 195, 676-679. doi: 10.1126/science.195.4279.676

Brasier, M. (2012). Secret Chambers: The Inside Story of Cells and Complex Life. Oxford: Oxford University Press.

Buick, R., Des Marais, D. J., and Knoll, A. H. (1995). Stable isotopic compositions of carbonates from the mesoproterozoic bangemall group, northwestern Australia. Chem. Geol. 123, 153-171. doi: 10.1016/0009-2541(95)00049-r

Butterfield, N. J. (2000). Bangiomorpha pubescens n. gen., n. sp.: implications for the evolution of sex, multicellularity, and the mesoproterozoic/neoproterozoic radiation of eukaryotes. Paleobiology 26, 386-404. doi: 10.1666/00948373(2000)026<0386:bpngns $>2.0 . c 0 ; 2$ 
Butterfield, N. J. (2005). Probable proterozoic fungi. Paleobiology 31, 165-182. doi: 10.1666/0094-8373(2005)031<0165:ppf > 2.0.co;2

Butterfield, N. J. (2014). Early evolution of the eukaryota. Palaeontology 58, 5-17. doi: $10.1111 /$ pala.12139

Chaimanee, Y., Jolly, D., Benammi, M., Tafforeau, P., Duzer, D., Moussa, I., et al. (2003). A middle miocene hominoid from Thailand and orangutan origins. Nature 422, 61-65. doi: 10.1038/nature01449

Chakrabarti, R., Knoll, A. H., Jacobsen, S. B., and Fischer, W. W. (2012). Si isotope variability in proterozoic cherts. Geochim. Cosmochim. Acta 91, 187-201. doi: 10.1016/j.gca.2012.05.025

Chen, J.-Y., Bottjer, D. J., Davidson, E. H., Dornbos, S. Q., Gao, X., Yang, Y.-H., et al. (2006). Phosphatized polar lobe-forming embryos from the precambrian of southwest China. Science 312, 1644-1646. doi: 10.1126/science.1125964

Chen, J.-Y., Bottjer, D. J., Davidson, E. H., Li, G., Gao, F., Cameron, R. A., et al. (2009). Phase contrast synchrotron X-ray microtomography of Ediacaran (Doushantuo) metazoan microfossils: phylogenetic diversity and evolutionary implications. Precambr. Res. 173, 191-200. doi: 10.1016/j.precamres.2009.04. 004

Chen, J.-Y., Schopf, J. W., Bottjer, D. J., Zhang, C.-Y., Kudryavtsev, A. B., Tripathi, A. B., et al. (2007). Raman spectra of a lower cambrian ctenophore embryo from southwestern Shaanxi, China. Proc. Natl. Acad. Sci. U.S.A. 104, 6289-6292. doi: 10.1073/pnas.0701246104

Cloud, P. E. (1983). "Early biogeologic history: the emergence of a paradigm," in Earth's Earliest Biosphere, Its Origin and Evolution, ed. J. W. Schopf (Princeton, NJ: Princeton University Press), 14-31.

Colbath, G. K., and Grenfell, H. R. (1995). Review of biological affinities of paleozoic acid-resistant, organic-walled eukaryotic algal microfossils (including “acritarchs"). Rev. Palaeobot. Palynol. 86, 287-314. doi: 10.1016/0034-6667(94) 00148-d

Darwin, C. R. (1859). On the Origin of Species. London: John Murray.

Dawson, J. W. (1875). The Dawn of Life. London: Hodder and Stoughton.

Degens, E. T., and Epstein, S. (1962). Relationship between $\mathrm{O}^{18} / \mathrm{O}^{16}$ ratios in coexisting carbonates, cherts, and diatomites. Am. Assoc. Pet. Geol. Bull. 46, $534-542$.

Donoghue, P. C. J., Bengtson, S., Dong, X.-P., Gostling, N., Huldtgren, T., Cuningham, J. A., et al. (2006). Synchrotron X-ray tomographic microscopy of fossil embryos. Nature 442, 680-683. doi: 10.1038/nature04890

Evitt, W. R. (1963). A discussion and proposals concerning fossil dinoflagellates, hystrichospheres and acritarchs. Proc. Natl. Acad. Sci. U.S.A. 49, 158-164. doi: 10.1073/pnas.49.2.158

Farquhar, J., Bao, H., and Thiemens, M. H. (2000). Atmospheric influence of Earth's earliest sulfur cycle. Science 289, 756-758. doi: 10.1126/science.289.5480.756

Feist, M., Liu, J., and Tafforeau, P. (2005). New insights into paleozoic charophytes morphology and phylogeny. Am. J. Bot. 92, 1152-1160. doi: 10.3732/ajb.92.7. 1152

Friis, E. M., Crane, P. R., Pedersen, K. R., Bengtson, S., Donoghue, P. C. J., Grimm, G. W., et al. (2007). Phase-contrast X-ray microtomography links Cretaceous seeds with gnetales and bennettitales. Nature 450, 549-553. doi: 10.1038/ nature 06278

Garcia, A. K., Schopf, J. W., Yokobori, S.-I., Akanuma, S., and Yamagishi, A. (2017). Reconstructed ancestral enzymes suggest long-term cooling of Earth's photic zone since the Archean. Proc. Natl. Acad. Sci. U.S.A. 91, 4619-4624. doi: 10.1073/pnas.1702729114

Garrels, R. M., and Mackenzie, F. T. (1971). Evolution of Sedimentary Rocks. New York: Norton.

Gaucher, E. A., Govindarajan, S., and Ganesh, O. K. (2008). Palaeotemperature trend for precambrian life inferred from resurrected proteins. Nature 451, 704-707. doi: 10.1038/nature06510

Gould, R. E. (1971). Lyssoxylon grigsbyi, a cycad trunk from the Upper Triassic of Arizona and New Mexico. Am. J. Bot. 58, 239-248. doi: 10.1002/j.1537-2197. 1971.tb09968.x

Haldane, J. B. S. (1929). Origin of life. Ration. Ann. 148, 3-10.

Han, T.-M., and Runnegar, B. (1992). Megascopic eukaryotic algae from the 2.1 billion-year-old negaunee iron formation, Michigan. Science 257, 232-235. doi: $10.1126 /$ science. 1631544

Hayes, J. M. (2001). Fractionation of carbon and hydrogen isotopes in biosynthetic processes. Rev. Miner. Geochem. 43, 225-277. doi: 10.1515/9781501508745-006
Holland, H. D. (2006). The oxygenation of the atmosphere and oceans. Philos. Trans. R. Soc. Biol. Sci. 361, 903-915. doi: 10.1098/rstb.2006.1838

Homann, M. (2019). Earliest life on earth: evidence from the barberton greenstone belt, South Africa. Earth Sci. Rev. 196:102888. doi: 10.1016/j.earscirev.2019. 102888

House, C. H., Schopf, J. W., McKeegan, K. D., Coath, C. D., Harrison, T. M., and Stetter, K. O. (2000). Carbon isotopic composition of individual Precambrian microfossils. Geology 28, 707-710. doi: 10.1130/0091-7613(2000)028<0707: cicoip > 2.3.co;2

Hren, M. T., Tice, M. M., and Chamberlain, C. P. (2009). Oxygen and hydrogen isotope evidence for a temperate climate 3.42 billion years ago. Nature 462, 205-208. doi: $10.1038 /$ nature 08518

Javaux, E. J. (2019). Challenges in evidencing the earliest traces of life. Nature 572, 451-460. doi: 10.1038/s41586-019-1436-4

Javaux, E. J., and Lepot, K. (2018). The paleoproterozoic fossil record: implications for the evolution of the biosphere during Earth's middle-age. Earth Sci. Rev. 176, 68-86. doi: 10.1016/j.earscirev.2017.10.001

Javaux, E. J., Knoll, A. H., and Walter, M. R. (2004). TEM evidence for eukaryotic diversity in mid-proterozoic oceans. Geobiology 2, 121-132. doi: 10.1111/j. 1472-4677.2004.00027.x

Kasting, J. F., Howard, M. T., Wallmann, K., Veizer, J., Shields, G., and Jaffés, J. (2006). Paleoclimates, ocean depth, and the oxygen isotopic composition of seawater. Earth Planet. Sci. Lett. 252, 82-93. doi: 10.1016/j.epsl.2006. 09.029

Knauth, L. P. (2005). Temperature and salinity history of the precambrian ocean: implications for the course of microbial evolution. Palaeogeogr. Palaeoclimatol. Palaeoecol. 219, 53-69. doi: 10.1016/b978-0-444-52019-7.50007-3

Knauth, L. P., and Lowe, D. R. (1978). Oxygen isotope geochemistry of cherts from the Onverwacht group (3.4 billion years), Transvaal, South Africa, with implications for secular variations in the isotopic composition of cherts. Earth Planet. Sci. Lett. 41, 209-222. doi: 10.1016/0012-821x(78)90011-0

Knauth, L. P., and Lowe, D. R. (2003). High Archean climatic temperature inferred from oxygen isotope geochemistry of cherts in the $3.5 \mathrm{Ga}$ Swaziland supergroup, South Africa. Geol. Soc. Am. Bull. 115, 566-580. doi: 10.1130/0016-7606(2003) $115<0566$ :hactif $>2.0$. co; 2

Knoll, A. H. (1992). The early evolution of eukaryotes: a geological perspective. Science 256, 622-627. doi: 10.1126/science.1585174

Knoll, A. H. (1994). Proterozoic and early cambrian protists - evidence for accelerating evolutionary tempo. Proc. Natl. Acad. Sci. U.S.A. 91, 6743-6750. doi: 10.1073/pnas.91.15.6743

Knoll, A. H., Javaux, E. J., Hewitt, D., and Cohen, P. A. (2006). Eukaryotic organisms in proterozoic oceans. Philos. Trans. R. Soc. Biol. Sci. 361, 1023-1038. doi: $10.1098 /$ rstb.2006.1843

Kolosov, P. N. (2016). New microorganisms from the Vendian (Ediacaran) of the Berezovsky trough, southern Siberian platform. Paleontol. J. 50, 549-556. doi: 10.1134/s0031030116060071

Kudryavtsev, A. B., Schopf, J. W., Agresti, D. G., and Wdowiak, T. J. (2001). In situ laser-Raman imagery of precambrian microscopic fossils. Proc. Natl. Acad. Sci. U.S.A. $98,823-826$. doi: $10.1073 /$ pnas. 98.3 .823

Logan, B. W. (1961). Cryptozoon and associate stromatolites from the recent, Shark Bay, Western Australia. J. Geol. 69, 517-533. doi: 10.1086/626769

Mendelson, C. V., Bauld, J., Horodyski, R. J., Lipps, J. H., Moore, T. B., and Schopf, J. W. (1992). "Proterozoic and selected early cambrian microfossils: prokaryotes and protists," in The Proterozoic Biosphere, A Multidisciplinary Study, eds J. W. Schopf and C. Klein (Cambridge: Cambridge University Press), 175-244. doi: 10.1017/cbo9780511601064.007

Miaoa, L., Moczydłowska, M., Zhu, S., and Zhua, M. (2019). New record of organicwalled, morphologically distinct microfossils from the late paleoproterozoic changcheng group in the Yanshan range, North China. Precambr. Res. 321, 172-198. doi: 10.1016/j.precamres.2018.11.019

Millay, M. A., and Eggert, D. A. (1974). Microgametophyte development in the paleozoic seed fern family callistophytaceae. Am. J. Bot. 61, 1067-1075. doi: 10.1002/j.1537-2197.1974.tb12324.x

Miller, S. L. (1953). Production of amino acids under possible primitive earth conditions. Science 117, 528-529. doi: 10.1126/science.117.3046.528

Miller, S. L., and Urey, H. C. (1959). Organic compound synthesis on the primitive earth. Science 130, 245-251. 
Olson, S. L., Schwieterman, E. W., Reinhard, C. T., and Lyons, T. W. (2018). "Earth: atmospheric evolution of a habitable planet," in Handbook of Exoplanets, eds $\mathrm{H}$. Deeg and J. Belmonte (Cham: Springer). doi: 10.1007/978-3-319-30648-3_1891

Oparin, A. I. (1924). Proiskhozhdenie Zhizni [The Origin of Life]. Moscow: Izd. Moskhovhii RabochiI. (in Russian).

Perry, E. C. (1967). The oxygen isotope chemistry of ancient cherts. Earth Planet. Sci. Lett. 3, 62-66. doi: 10.1016/0012-821x(67)90012-x

Pietrzak-Renaud, N., and Davis, D. (2014). U-pb geochronology of baddeleyite from the belleview metadiabase: age and geotectonic implications for the negaunee iron formation, Michigan. Precambr. Res. 250, 1-5. doi: 10.1016/j. precamres.2014.05.018

Poulton, S. W., Bekker, A., Cumming, V. M., Zerkle, A. L., Canfield, D. E., and Johnston, D. T. (2021). A 200-million-year delay in permanent atmospheric oxygenation. Nature 592, 232-236. doi: 10.1038/s41586-021-03393-7

Prasad, B., Uniyal, S. N., and Asher, R. (2005). Organic-walled microfossils from the proterozoic vindhyan supergroup of Son Valley, Madhya Pradesh, India. Palaeobotanist 54, 13-60.

Ray, J. S., Martin, M. W., Veizer, J., and Bowring, S. A. (2002). U-Pb zircon dating and $\mathrm{Sr}$ isotope systematics of the Vindhyan supergroup, India. Geology 30, 131-134.

Risso, V. A., Gavira, J. A., and Mejia-Carmona, D. F. (2013). Hyperstability and substrate promiscuity in laboratory resurrections of precambrian b-lactamases. J. Am. Chem. Soc. 135, 2899-2902. doi: 10.1021/ja311630a

Robert, F., and Chaussidon, M. (2006). A palaeotemperature curve for the precambrian oceans based on *silicon isotopes in cherts. Nature 443, 969-972. doi: 10.1038 /nature05239

Runnegar, B. (1994). "Proterozoic eukaryotes: evidence from biology and geology," in Early Life on Earth, Nobel Symposium No. 84, ed. S. Bengtson (New York, NY: Columbia University Press), 287-297.

Schidlowski, M. (1991). Organic carbon isotope record: index line of autotrophic carbon fixation over 3.8 Gyr of earth history. J. Southeast Asian Earth Sci. 5, 333-337. doi: 10.1016/0743-9547(91)90045-Y

Schidlowski, M., Hayes, J. M., and Kaplan, I. R. (1983). "Isotopic inferences of ancient biochemistries: carbon, sulfur, hydrogen, and nitrogen," in Earth's Earliest Biosphere, Its Origin and Evolution, ed. J. W. Schopf (Princeton, NJ: Princeton University Press), 149-186.

Schirrmeister, B. E., Sanchez-Baracaldo, P., and Wacey, D. (2016). Cyanobacterial evolution during the precambrian. Int. J. Astrobiol. 15, 187-204. doi: 10.1017/ S1473550415000579

Schopf, J. W. (1968). Microflora of the bitter springs formation, late precambrian, Central Australia. J. Paleontol. 42, 651-688.

Schopf, J. W. (1970). Electron microscopy of organically preserved precambrian microorganisms. J. Paleontol. 44, 1-6.

Schopf, J. W. (1993). Microfossils of the early Archaean apex chert: new evidence of the antiquity of life. Science 260, 640-646. doi: 10.1126/science.260.5108.640

Schopf, J. W. (1994). Disparate rates, differing fates: the rules of evolution changed from the precambrian to the phanerozoic. Proc. Natl. Acad. Sci. U.S.A. 91, 6735-6742. doi: 10.1073/pnas.91.15.6735

Schopf, J. W. (ed.) (1983). Earth's Earliest Biosphere, Its Origin and Evolution. Princeton, NJ: Princeton University Press.

Schopf, J. W., and Blacic, J. M. (1971). New microorganisms from the bitter springs formation (late precambrian) of the north-central Amadeus Basin, Australia. J. Paleontol. 45, 925-960.

Schopf, J. W., and Klein, C. (eds) (1992). The Proterozoic Biosphere, A Multidisciplinary Study. Cambridge: Cambridge University Press. doi: 10.1017/ CBO9780511601064

Schopf, J. W., and Kudryavtsev, A. B. (2005). Three-dimensional Raman imagery of precambrian microscopic organisms. Geobiology 3, 1-12. doi: 10.1111/j.14724669.2005.00044.x

Schopf, J. W., and Oehler, D. Z. (1976). How old are the eukaryotes? Science 193, 47-49.

Schopf, J. W., Barghoorn, E. S., Maser, M. D., and Gordon, R. O. (1965). Electron microscopy of fossil bacteria two billion years old. Science 149, 1365-1367. doi: 10.1126/science.149.3690.1365

Schopf, J. W., Ford, T. D., and Breed, W. J. (1973a). Microorganisms from the late precambrian of the Grand Canyon, Arizona. Science 179, 1319-1321.
Schopf, J. W., Haugh, B. N., Molnar, R. E., and Satterthwait, D. F. (1973b). On the development of metaphytes and metazoans. J. Paleontol. 47, 1-9.

Schopf, J. W., Kitajima, K., Spicuzza, M. J., Kudryavtsev, A. B., and Valley, J. W. (2018). SIMS analyses of the oldest known assemblage of microfossils document their taxon-correlated carbon isotope compositions. Proc. Natl. Acad. Sci. U.S.A. 115, 53-58. doi: 10.1073/pnas.1718063115

Schopf, J. W., Kudryavtsev, A. B., Agresti, D. G., Czaja, A. D., and Wdowiak, T. J. (2005). Raman imagery: a new approach to assess the geochemical maturity and biogenicity of permineralized precambrian fossils. Astrobiology 5, 333-371. doi: 10.1089/ast.2005.5.333

Schopf, J. W., Kudryavtsev, A. B., Agresti, D. G., Wdowiak, T. J., and Czaja, A. D. (2002). Laser-Raman imagery of Earth's earliest fossils. Nature 416, 73-76. doi: $10.1038 / 416073 a$

Schopf, J. W., Kudryavtsev, A. B., Osterhout, J. T., Williford, K. H., Kitajima, K., Valley, J. W., et al. (2017). An anaerobic 3400 Ma shallow-water microbial consortium: presumptive evidence of Earth's paleoarchean anoxic atmosphere. Precambr. Res. 299, 309-318. doi: 10.1016/j.precamres.2017.07.021

Schopf, J. W., Tripathi, A. B., and Kudryavtsev, A. B. (2006). Three-dimensional confocal optical microscopy of precambrian microscopic organisms. Astrobiology 6, 1-16. doi: 10.1089/ast.2006.6.1

Sepkoski, J. J., and Schopf, J. W. (1992). "Biotic diversity and rates of evolution during proterozoic and earliest phanerozoic time," in The Proterozoic Biosphere, A Multidisciplinary Study, eds J. W. Schopf and C. Klein (Cambridge: Cambridge University Press), 521-566.

Seward, A. C. (1931). Plant Life Through the Ages. Cambridge: Cambridge University Press.

Sharma, M., and Shukla, Y. (2009a). Mesoproterozoic coiled megascopic fossil Grypania spiralis from the rohtas formation, semri group, Bihar, India. Curr. Sci. 96, 1636-1640.

Sharma, M., and Shukla, Y. (2009b). Taxonomy and affinity of early mesoproterozoic megascopic helically coiled and related fossils from the rohtas formation, the Vindhyan supergroup, India. Precambr. Res. 173, $105-122$.

Simpson, G. G. (1944). Tempo and Mode in Evolution. New York, NY: Columbia University Press.

Tafforeau, P., Boistel, R., Boller, E., Bravin, A., Brunet, M., Chaimanee, Y., et al. (2006). Applications of X-ray synchrotron microtomography for nondestructive 3D studies of paleontological specimens. Appl. Phys. A Mater. Sci. Process. 83, 195-202. doi: 10.1007/s00339-006-3507-2

Talyzina, N. M. (2000). Ultrastructure and morphology of Chuaria circularis (Walcott, 1899) Vidal and Ford (1985) from the neoproterozoic visingsö group, Sweden. Precambr. Res. 102, 123-134. doi: 10.1016/S0301-9268(00)00062-0

Tang, H., Trail, D., Bell, E. A., and Harrison, T. M. (2019). Zircon halogen geochemistry: insights into Hadean-Archean fluids. Geochem. Perspect. Lett. 9, 49-53. doi: 10.7185/geochemlet.1905

Thiemens, M. H., and Heidenreich, J. E. (1983). The mass-independent fractionation of oxygen: a novel effect and its possible cosmochemical implications. Science 219, 1073-1075. doi: 10.1126/science.219.4588.1073

Timofeev, B. F., and Hermann, T. N. (1979). "Dokembriiskaya microbiota Lachandinskoi svity [Precambrian microbiota of the Lakhanda formation]," in Paleontologiya Dokembriya I Rannego Kembriya [Paleontology of the Precambrian and Early Cambrian], ed. B. S. Sokolov (Leningrad: Nauka), 137-147. (in Russian).

Tomescu, A. M. F., Klymiuk, A. A., Matsunaga, K. K. S., Bippus, A. C., and Shelton, G. W. K. (2016). "Microbes and the fossil record: selected topics in paleomicrobiology," in Their World: A Diversity of Microbial Environments, Advances in Environmental Microbiology 1, ed. C. J. Hurst (Cham: Springer), 69-169.

Towe, K. M., Bengtson, S., Fedonkin, M. A., Hofmann, H. J., Mankiewicz, C., and Runnegar, B. N. (1992). "Proterozoic and earliest cambrian carbonaceous remains: trace and body fossils," in The Proterozoic Biosphere, A Multidisciplinary Study, eds J. W. Schopf and C. Klein (Cambridge: Cambridge University Press), 343-402.

Tyler, S. A., and Barghoorn, E. S. (1954). Occurrence of structurally preserved plants in pre-cambrian rocks of the Canadian shield. Science 119, 606-608. doi: 10.1126/science.119.3096.606

Van Kranendonk, M. J., Baumgartner, R., Djokic, T., Ota, T., Steller, L., Garbe, U., et al. (2021). Elements for the origin of life on land: a deep-time perspective 
from the Pilbara Craton of Western Australia. Astrobiology 21, 39-59. doi: 10.1089/ast.2019.2107

Walcott, C. D. (1899). Precambrian fossiliferous formations. Geol. Soc. Am. Bull. 10, 199-244. doi: 10.1130/GSAB-10-199

Walter, M. R. (1977). Interpreting stromatolites. Am. Sci. 65, 563-571.

Walter, M. R. (ed.) (1973). Stromatolites: Advances in Sedimentology, Vol. 20. Amsterdam: Elsevier.

Weis, D., and Wasserburg, G. J. (1987). Rb-Sr and Sm-Nd isotope geochemistry and chronology of cherts from the Onverwacht group (3.5 AE), South Africa. Geochim. Cosmochim. Acta 51, 973-984. doi: 10.1016/0016-7037(87)90109-8

Wells, J. W. (1963). Coral growth and geochronometry. Nature 197, 948-950. doi: 10.1038/197948a0

Wilde, S. A., Zhao, G., Wang, K., and Sun, M. (2004). First SHRIMP zircon U-Pb ages for hutuo group in Wutaishan: further evidence for palaeoproterozoic amalgamation of North China Craton. Chin. Sci. Bull. 49, 83-90. doi: 10.1007/ BF02901747

Xiao, S., Knoll, A. H., Yuan, X., and Pueschel, C. M. (2004). Phosphatized multicellular algae in the neoproterozoic doushantuo formation, China, and the early evolution of florideophyte red algae. Am. J. Bot. 91, 214-227. doi: 10.3732/ajb.91.2.214

Yamagishi, A., Kon, T., Takahashi, G., and Oshima, T. (1998). "From the common ancestor of all living organisms to protoeukaryotic cell," in Thermophiles: The Key To Molecular Evolution And The Origin of Life? eds J. Wiegel and M. Adams (London: Taylor and Francis), 287-295.

Yin, L., Meng, F., Kong, F., and Niu, C. (2020). Microfossils from the paleoproterozoic hutuo group, Shanxi, North China: early evidence for eukaryotic metabolism. Precambr. Res. 342:105650. doi: 10.1016/j.precamres. 2020.105650
Yin, Z., Zhu, M., Davidson, E. H., Bottjer, D. J., Zhao, F., and Tafforeau, P. (2015). Sponge grade body fossil with cellular resolution dating $60 \mathrm{Myr}$ before the cambrian. Proc. Natl. Acad. Sci. U.S.A. 112, E1453-E1460. doi: 10.1073/pnas. 1414577112

Yochelson, E. (1998). Charles Doolittle Walcott, Paleontologist. Kent, OH: Kent State University Press.

Zhu, S., Zhu, M., Knoll, A. H., Yin, Z., Zhao, F., Sun, S., et al. (2016). Decimetrescale multicellular eukaryotes from the 1.56-billion-year-old gaoyuzhuang formation in North China. Nat. Commun. 7:11500. doi: 10.1038/ncomms 11500

Conflict of Interest: The author declares that the research was conducted in the absence of any commercial or financial relationships that could be construed as a potential conflict of interest.

Publisher's Note: All claims expressed in this article are solely those of the authors and do not necessarily represent those of their affiliated organizations, or those of the publisher, the editors and the reviewers. Any product that may be evaluated in this article, or claim that may be made by its manufacturer, is not guaranteed or endorsed by the publisher.

Copyright (c) 2021 Schopf. This is an open-access article distributed under the terms of the Creative Commons Attribution License (CC BY). The use, distribution or reproduction in other forums is permitted, provided the original author(s) and the copyright owner(s) are credited and that the original publication in this journal is cited, in accordance with accepted academic practice. No use, distribution or reproduction is permitted which does not comply with these terms. 